\title{
Олександр Яневич
}

\section{РАННЬОМЕЗОЛІТИЧНІ ПОМЕШКАННЯ В ГРОТІ ШПАН-КОБА (КРИМ, УКРАÏНА)}

\begin{abstract}
Метою статі $\epsilon$ введення в науковий обіг та аналіз результатів розкопок нижніх, ранньомезолітичних шарів

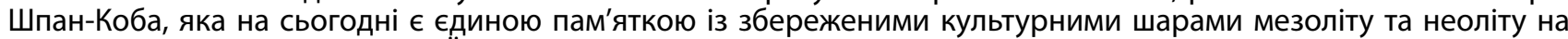
Першому пасмі Кримських гір. Ії матеріали дозволяють скласти чітку уяву щодо хронології, культурної приналежності, господарства та стратегії заселення у мезоліті та неоліті цієї частини Гірського Криму. Ранньомезолітичні культурні шари належать до типу «ефемерних». Вони представлені невеликими вогнищами, поодинокими крем'яними виробами та кістками тварин. ІІх планіграфія, кількість та склад крем'яних артефактів, біля половини із яких припадає на знаряддя, свідчать, що грот Шпан-Коба використовувався у якості житла під час спорадичних, надзвичайно короткотермінових відвідин яйл невеликими групами свідерських мисливців в ранньому пребореалі з метою полювання на сугака, оленя та ведмедя в теплу пору року (весна та літо).
\end{abstract}

Ключові слова: Крим, Україна, ранній мезоліт, помешкання, житло, сезонні міграції, свідер.

\section{ВСТУП}

Печерні житла були одними із найдавніших природних прихистків первісних людей. У якості «печерних» жител використовувались різні за розмірами та походженням типи великих скельних порожнин - насамперед, неглибокі скельні навіси та гроти, або, дуже рідко, привхідні частини власне печер - довгих порожнин, як правило, карстового походження. Популярність скельних прихистків у первісності пояснюється кількома чинниками. По-перше - вони були природними помешканнями, які не вимагали додаткового облаштування, або ж воно було мінімальним. Подруге - забезпечували надійний захист від негоди та хижаків. I, нарешті, скельні масиви, в яких знаходились печери, були природними тепловими акумуляторами: вони зберігали прохолоду вдень та тепло вночі. Вочевидь, тому природні або штучні печери $\epsilon$ архітектурними складовими житлових та господарських будівель і сьогодні в багатьох гірських районах, наприклад, у пізньопалеолітичному скельному навісі Ложері-Бас у Франції (рис. 1).

Кримські гори складаються із вапняків, а отже, містять надзвичайно багато різноманітних за походженням та розмірами скельних порожнин. В передгір'ях, у зоні Другого пасма Кримських гір, поширені передусім неглибокі навіси та гроти у скельних обривах, які були найбільш принадними для житла. У багатьох із них розташовані стоянки кам'яної доби. Найдавніші з них належать ще до середнього палеоліту. Відомі печерні пам'ятки пізнього палеоліту. Численними вони були в фінальному палеоліті та ранньому мезоліті (рис. 2), а згодом і в пізньому мезоліті, неоліті та енеоліті. Найпізніші виразні помешкання в навісах та гротах датуються добою бронзи та раннього заліза. Спорадично використовувались природні та вже спеціально вирубані скельні камери також в античності та середньовіччі. Хоча в ці епохи, особливо в середньовіччі, вони слугували вже здебільше для господарських потреб або як культові споруди - так звані «печерні міста».

На Першому пасмі Кримських гір, навпаки, переважають глибокі, як правило, вертикальні карстові печери, які були не придатні для заселення. Печерні стоянки на Першому пасмі розташовуються на плоскогір'ях — так званих яйлах. На відміну від Другого пасма тут вони поодинокі - для всіх яйл відомі лише декілька печерних стоянок: середньопалеолітична Карабі-Тамчин та середньо - та пізньопалеолітична Аджи-Коба на Карабі-яйлі, мезолітична та неолітична ШпанКоба на Субаткан-яйли та одна пізньопалеолітична стоянка на Чатир-Дагу.

Шпан-Коба займає серед них особливе місце, це - єдина на сьогодні пам'ятка зі збереженими культурними шарами мезоліту та неоліту на Пер- 
шому пасмі Кримських гір, яка дозволяє скласти чітку уяву щодо хронології, культурної приналежності, господарства та стратегії заселення у мезоліті та неоліті цієї частини Гірського Криму. Метою пропонованої статі $\epsilon$ введення в науковий обіг та аналіз результатів розкопок нижніх, ранньомезолітичних шарів пам'ятки, зокрема, з'ясування стратегії освоєння яйл та заселення гроту ШпанКоба в ранньому пребореалі.

\section{СТОЯНКА ШПАН-КОБА}

Шпан-Коба розташована на Головному пасмі Кримських гір, на північно-східному краю Субатканяйли, в верхів'ях балки Чау-Кетау, яка впадає в

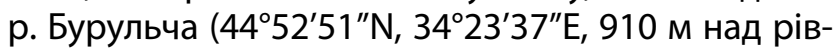
нем океану) (рис. 2). Пам'ятка знаходиться на лівому березі балки, в гроті, який являє собою устя давньої карстової печери. Його ширина сягає 15 м, глибина біля 5 м. далі він переходить в низьку, завалену камінням карстову печеру (рис. 3). Грот в наш час сухий, має південно-східну експозицію. Перед ним $\epsilon$ трохи похила велика площадка.

Стоянка була відкрита С.А. Трусовою в 1925 р. В 1938 р. в гроті був поставлений розвідувальний шурф експедицією Інституту антропології МДУ, яка працювала під керівництвом О.М. Бадера (Бадер 1957). Документація та археологічний матеріал із розкопок 1925 та 1938 рр. не збереглися. В 1988-1989 рр. стоянка досліджувалася Кримською мезолітичною експедицією Інституту археології АН УРСР (керівник О.О. Яневич). В 1988 р. були поставлені два розвідувальних шурфи розміром 1 × 2: в самому гроті (шурф №1) та на площадці перед ним (шурф №2) (рис. 4). В 1989 р. на стоянці

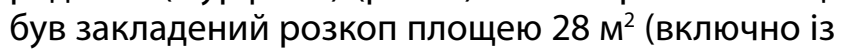
шурфом 1988 р.). Культурні шари неоліту, пізнього та середнього мезоліту були розкопані на всій його площі. При дослідженні ж ранньомезолітичних шарів квадрати ліній 11 та 12 були виключені із розкопок у зв'язку із очевидним виклинюванням культурних шарів середнього мезоліту в південно-західній частині гроту.

Грот використовувався в історичний час. Верхня частина відкладів в ньому, разом з культурними шарами раннього заліза, доби бронзи (літологічний шар A1), на більшій його площі була вичищена при використанні грота як загону для овець. Внаслідок цього, під сучасними відкладами пухкого ґрунту з домішками вугілля, золи та гною одразу залягали культурні шари неоліту.

Поздовжній профіль розкопу по лінії «и» мав наступну стратиграфію (рис. 5):

Літологічний шар А2. Червонувато-коричневий суглинок з великою домішкою попелу та вугілля. Містив залишки шару неоліту (шар 1-1). Потужність 15 см.

Літологічний шар В. Жовтувато-коричневий глинистий суглинок $з$ щебенем. В чистому вигляді простежений лише на периферії розкопу. На більшій же частині розкопу містив вогнища, мав значну домішку вугілля та золи. Внаслідок цього відклади літологічного шару здебільше були сірого або темно-сірого забарвлення. Містив культурні шари пізнього мезоліту (шар 1-2, 1-3). Потужність $40-50 \mathrm{~cm}$.

Літологічний шар С. Червонувато-коричневий глинистий суглинок з уламками, значними домішками золи та деревинного вугілля. Містив культурний шар середнього мезоліту (шар 1-4, 5). Потужність 10-20 см.

Літологічний шар D. Жовтувато-брунатний суглинок без щебеню. Добре простежував в центральній та східній частинах розкопу, на захід та північ поступово зникає. Стерильний. Потужність $15-20 \mathrm{cM}$.

Літологічний шар Е. Червоно-коричневий суглинок з щебенем. Як і в подібному верхньому шарі, в чистому вигляді простежувався лише в нижній частині шару Верхня ж частина внаслідок домішок вугілля та золи мала темно-сірий колір. В центральній частині розкопу, простежено декілька розташованих одне над одним лінз вогнищ з вуглисто-зольним заповненням та прошарками пропеченої глини під ними. Літологічний шар містив археологічні матеріали середнього мезоліту (шари 2-1; 2-2; 2-3; 2-4/5). Потужність 40-50 см.

Літологічний шар F. Жовтувато-брунатний глинистий суглинок, без уламкового матеріалу. Займав східну та центральну частини розкопу. В північній та західній частинах розкопу поступово зникав. Містив «ефемерні» шари раннього мезоліту з тонкими лінзами вогнищ або вугіллям, поодинокими крем'яними виробами та кістками тварин (шари 3-1; 3-2; 3-3; 3-4 та 3-5/6). Потужність до 60 см.

Літологічний шар G. Червоно-коричневий суглинок з щебенем. Щебінь здебільше крупніший, ніж в попередніх двох шарах червонокоричневого суглинку 3 щебенем. Стерильний. Потужність до 80 см.

Літологічний шар Н. Яскрава червона глина 3 великою домішкою дрібної кварцової гальки та піску. Аналогічні відклади дуже рідко зустрічається на яйлах. Зокрема, вони $є$ поблизу печерної котловини на Чатир-Дагу. Походження їх не зовсім з'ясоване. Ймовірно, що це - глина та галька із зруйнованої брекчії, яка винесена під час утворення карстової порожнини Шпан-Коби. Стерильний. Потужність до $10 \mathrm{~cm}$.

Літологічний шар І. Скельне дно навісу. Понад 2,4 м від сучасної денної поверхні.

Отже, відклади стоянки містили культурні шари пізньої бронзи, неоліту, пізнього, середнього та раннього мезоліту. Культурні шари пізньої бронзи та неоліту були добре представлені на площадці перед гротом, в шурфі №2. 3 мезолі- 
тичних шарів тут фрагментарно простежувалися лише середньомезолітичні. В гроті, в розкопі, представлені нижні культурні шари: неоліту, пізнього, середнього та раннього мезоліту. У відповідності із стратиграфією пам'ятки, для їх позначення була використана наступна номенклатура. Шари, які залягали в літологічному шарі F, були позначені як культурні шари археологічного юніту 3 - культурні шари 3-5/6, 3-4, 3-3, 3-2 та 3-1 (ранній мезоліт). Шари, пов'язані із літологічним шаром Е позначені як культурні шари археологічного юніту 2 - культурні шари 2-4/5, 2-2, 2-3 та 2-1 (середній мезоліт). Культурні шари, які простежені в літологічному шарі C, позначений як 1-4/5 (середній мезоліт). Культурні шари, пов'язані із літологічним шаром B, як 1-3, 1-2, 1-1 (пізній мезоліт) та культурний шар, який залягав в літологічному шарі A2, як 1-1а (неоліт).

\section{КУЛЬТУРНІ ШАРИ ЮНІТУ 3}

Самі нижні культурні шари - юніту 3, простежувались по вираженим житловим структурам вогнищам, та вкрай незначною кількістю артефактів: крем'яних виробів та кісток тварин, а в окремих шарах також за домішкою деревинного вугілля в седименті. Вони мали надзвичайно чітку стратиграфічну позицію і були відокремлені один від одного прошарками стерильного суглинку потужністю від 2 до $10 \mathrm{~cm}$.

КУЛЬТУРНИЙ ШАР 3-5/6 - самий нижній на стоянці. Стратиграфічно він пов'язаний із нижньою частиною відкладів літологічного шару $\mathrm{F}$ : його археологічні матеріали залягали на декілька сантиметрів вище контакту літологічних шарів $G$ та $F$. Завдяки темному, брунатного кольору суглинку, який містив невелике включення дуже дрібного деревинного вугілля та, можливо, органічну домішку, культурний шар 3-5/6 чітко простежувався стратиграфічно та планіграфічно на більшій частині розкопу, за виключенням квадратів лінії «ж» та кв. 63, де відклади містили лише окремі вуглинки та седимент набував жовтуватого кольору (рис. 6). у зв'язку з великою потужністю культурний шар був розкопаний двома горизонтами - 3-5 та 3-6.

Культурний шар 3-5/6 складався 3 трьох житлових поверхонь, які фіксують його окремі вогнища. Вони розташовувались в центральній частині розкопу на різних стратиграфічних рівнях (рис. 6).

Найнижчу стратиграфічну позицію займало вогнище №1. Воно знаходилось в кв. 7й, було пласке, овальне в плані, розмірами по осі південьпівніч - 0,60 м, по осі схід-захід - 0,90 м. Лінза вогнища мала інтенсивне вуглисте заповнення темно-сірого кольору. Ії̈ максимальна потужність сягала біля 3 см. Під лінзою, на всій площі вогнища, за виключенням лише західної периферії, простежений прокал темно-коричневого кольору потужністю до 2 см.
Вогнища №2 та №3 розташовувались в кв. 7и, 8и та, частково, 7з та 83. Вони залягали дещо вище, хоча, різниця в нижніх відмітках вогнища №1 та самого нижнього $з$ двох інших вогнищ вогнища №2, була вкрай незначною, всього 3 см. Вогнища №2 та 3 були також пласкі, підокруглої, дещо витягнутої форми. Вони мали майже однакові розміри: з південного заходу на північний схід біля 1,45 м, а з північного заходу на південний схід біля 1,20 м. Вуглисті лінзи вогнищ розташовувались одна над одною, співпадаючи в плані. Як окремі об'єкти вони простежувались в північносхідній та центральній частинах. Тут вони мали чітко виражені лінзи з інтенсивним вуглистим заповненням темно-сірого кольору, що видно на профілі відкладів розкопу (рис. 5). Кожна 3 лінз була потужністю біля 3 см та підстилалась прокалом темно-коричневого кольору до 2,5 cм. Їх розділяв прошарок стерильної глини завтовшки до 4 см. В південно-західній частині обидві вуглисті лінзи вогнищ змикались в одну, потужністю до 11 см. Прокал в цій частині вогнищ був відсутній. Контури вогнищ №2 та №3 в північно-східній частині були чіткі. Натомість в південно-західній частині інтенсивність вмісту деревинного вугілля в їхній спільній лінзі значно зменшувалась і вона поступово переходила в темні, слабко насичені деревинним вугіллям відклади культурного шару.

Крім вогнищ, надзвичайно цікавим об'єктом культурного шару 3-5/6 є стіна в кв.7з та 7и (рис. 6). ІІї утворювали дев'ять каменів розміром від 20 до 50 см. Вони були покладені в ряд, а в центральній частині - у два ряди. Довжина стіни сягала 1,50 см, а ширина в центральній частині до 0,40 см. Штучне походження стіни, з огляду на відсутність будь-якого уламкового вапнякового матеріалу в літологічному шарі $F$, не викликає сумнівів. Іїі спорудили, безперечно, під час функціонування вогнища №2. На це вказує: по-перше, співпадіння нівеліровочних відміток низу вогнища №2 та більшості каменів, по-друге, чітке обмеження каменями північно-східного контуру вогнища №2 та розташованого безпосередньо над ним вогнища №3 i, нарешті, перекриття крайніми південно-східними каменями північно-західної периферії лінзи вогнища №1 - найнижчого за нівеліровочними відмітками (рис. 5 та 6). Отже, стіна була споруджена, скоріш за все, як частина конструкції вогнища №2. Дещо пізніше, судячи 3 розташування вогнища №3 та обмеженням каменями його лінзи, вона використовувалась і для цього вогнища.

Можливо, ця штучна споруда була складовою більш складної житлової конструкції. На південний схід від вогнищ в південно-східній стінці розкопу знаходились великі камені (рис. 6). Частина із них, в кв. 9й, була розкопана. Це чотири великих 
камені розмірами від 0,70 × 50 м до 1,00 × 0,40 м. Вони лежали один на одному. В кв. бй повністю розкопаний невеликий камінь, розмірами 0,30 x 0,20 м, та частково великий, більше 1,0 м завдовжки та завширшки. В кв. 10й частково був розкопаний ще один великий камінь. Його розкопані розміри також перевищували 1,0 м. Розташування каменів в культурному шарі 3-6 на лінії кв. 6й могло бути як природним, так і штучним. Вони знаходяться на крапельній лінії гроту, яка співпадає 3 краєм його піддашшя. Отже, ймовірно, камені мають природне походження, тобто впали під час руйнації краю піддашшя. Але не можна виключати й штучний характер розташування каменів та зв'язок їх з культурним шаром 3-6. Підставами для такого припущення $\epsilon$ співпадіння нівеліровочних відміток низу каменів з нівеліровочними відмітками культурного шару та, особливо, розташування каменів в кв. 9й один на одному, що $є$ маловірогідним для їхнього природного розташування. Суперечать припущенню щодо штучного розташування каменів великі розміри деяких із них, особливо каменів в кв. бй та 10й. Але, незважаючи на великі розміри, камені були пласкі - завтовшки від 8 до 40 см, отже, цілком могли бути переміщені людьми. Виключенням $\epsilon$ лише камінь в кв. 10й, який був надто великий та важкий, щоб його можна було зрушити з місця. Таким чином, розташування каменів по лінії «й» і споруда, частиною якої вони могли бути, мало, скоріш за все, частково природній характер (камінь в кв. 10й та, можливо, камінь в кв. бй) та частково штучний (решта каменів, насамперед, в кв. 9й). Цікаво, що вже в історичний час саме по лінії квадратів «ж» була споруджена кам'яна стіна для облаштування гроту під загін для овець.

Ще однією $з$ ознак існування в культурному шарі штучного житла може бути характер поширення відкладів, за яким простежувався культурний шар - темного, брунатного кольору суглинку. Нагадаємо, він містив дуже дрібне деревинне вугілля та, можливо, органічну домішку, та був добре представлений на більшій частині розкопу, але водночас був відсутній у північно-західній частині розкопу (у кв. лінії «ж» та у кв. 6з). Такий розподіл темних відкладів ніяк не можна пояснити конфігурацією гроту - в розташованих вище культурних шарах середнього та пізнього мезоліту тут були розкопані вогнища. Водночас, їхня чітка межа поширення цілком може пояснюватись певною штучною перешкодою, зокрема, стіною житла, наприклад, куреню, складеного з гілок дерева з листям.

Отже, підбиваючи підсумки розгляду мікростратиграфії та планіграфії культурного шару 3-5/6, можна зробити наступні висновки. Поперше, шар відклався в результаті принаймні трьох (за кількістю вогнищ) заселень гроту. Подруге, накопичення його відкладів відбулось, судячи з близьких стратиграфічних позицій вогнищ, за короткий час. Не виключено, що його залишила одна й та ж група людей, зважаючи на розташування вогнищ №2 та №3 одне над одним. Нарешті, заповнення шару з домішкою дрібного вугілля, яке має чіткі межі, кам'яна викладка біля вогнищ та камені в південно-східній стінці розкопу дають підстави припускати існування в культурному шарі житлової споруди, можливо, куреню з гілок.

Археологічні матеріали культурного шару 3-5/6 - крем'яні артефакти та кістки тварин, були пов'язані, здебільше, з верхньою частиною темних, дещо вуглистих відкладів культурного шару, або ж залягали безпосередньо на них. Вони знаходились майже на всій площі розкопу. Утім, при цьому простежується їхній загальний зв'язок із вогнищами. Натомість у квадратах крайніх ліній розкопу артефакти були відсутні (рис. 6). Привертає увагу також смуга без знахідок завширшки від 0,5 до 1,0 м, яка простягалась навколо вогнищ №2 та №3 з північного-заходу до південного-сходу, за якою, на захід та південь, розташовувались крем'яні вироби та кістки.

Крем'яний комплекс вкрай нечисленний - він складається всього з десяти виробів. До нього входять нуклеус, мікроплатівка 3 притупленим краєм, різець, скребачка, чотири платівки та три відщепи (рис. 11: 12-21). Нуклеус - одноплощинний, із короткою неправильною в плані та широкою поверхнею сколювання (рис. 11: 22). Зона розщеплення редукована дрібною ретушшю. Площадка пряма, сформована одним сколом, гладка. Судячи з товщини нуклеусу, він був спрацьований. Мікроплатівка з притупленим краєм (рис. 11: 14) має дрібну притуплюючу ретуш по одному краю. На одному 3 кінців, з вентральної сторони, $\epsilon$ пласка фасетка, ймовірно, макропошкодження внаслідок використання в якості бокового вкладеня наконечника метальної зброї. Різець - серединний, на масивній платівці, знятій 3 двоплощинного нуклеусу, із залишками жовневої кірки на дистальній частині (рис. 11: 16). Скребачка - невелика, кінцева, на неправильній платівці, знятій з двоплощинного нуклеусу, має ретушовані бокові сторони та основу (рис. 11: 20). Платівки невеликі, правильні. Дві з них сколоті з двоплощинного нуклеусу (рис. 11: 12, 13) та дві з одноплощинного (рис. 11: 17, 18), в тому числі одна, можливо, відтискним способом (рис. 11: 18). Всі мають фасетки використання на краях. Крім того, одна з них має також частково ретушований з дорсальної сторони кінець (рис. 11: 13). Можливо, вона, використовувалась в якості бокового вкладеня метальної зброї. 3 трьох відщепів один має ретуш використання (рис. 11: 19). 
Культурна приналежність шару 3-5/6 до свідерської культури не можна визначити беззаперечно. Утім, переважання серед платівчастих сколів виробів, знятих з двоплощиних нуклеусів, та різець, морфологічно майже ідентичний різцю 3 культурного шару 3-2 (рис. 11: 7), де був знайдений також свідерський наконечник, дають вагомі підстави припускати, що культурний шар 3-5/6 був залишений свідерцями. Не суперечить цьому припущенню присутність мікроплавки з притупленим краєм та платівки, можливо, отриманої відтиском з одноплощинного нуклеусу. В розташованому вище свідерському комплексі культурного шару 3-2 стоянки також $\epsilon$ мікроплатівка 3 притупленим краєм, а загалом використання композитних пазових наконечників з боковими вкладенямимікроплатівками з притупленим краєм можна припускати для свідерського шару 4 Буран-Каї 3, відтискна ж техніка в Свідері Криму добре відома за матеріалами Сюрені II (Ступак 1999).

Археозоологічні матеріали шару 3-5/6 найчисленніші серед культурних шарів юніту 3 та надзвичайно різноманітні за складом - в їхньому складі кістки сугака, оленя благородного, ведмедя бурого, коня дикого, лисиці звичайної, зайця сірого та хом'яка (табл. 2).

КУЛЬТУРНИй ШАР 3-4 пов'язаний з середньою частиною літологічного шару $\mathrm{F}$ - він залягав безпосередньо під другим прошарком білоглазки (рис. 5). Від розташованого вище культурного шару 3-5/6 відділявся прошарком стерильного суглинку потужністю біля 10 см, від перекриваючого культурного шару 3-3 - прошарком стерильного суглинку потужністю 5-6 см.

Шар простежений в центральній та південнозахідній частинах розкопу по вогнищу та кільком кісткам тварин (рис. 7). Вогнище знаходилось в центральній частині розкопу, в кв. 83. Воно було пласке, округле в плані, розмірами з південного заходу на північний схід - 1,20 м, а 3 північного заходу на південний схід - 1,0 м. Лінза сірого кольору, мала включення деревинного вугілля різних розмірів та невелику домішку попелу. ІІї максимальна потужність в центральній частині сягала 3 см. В південно-західній частині вогнища під лінзою простежувався пропечений суглинок потужністю до 1 см. Майже всі кістки були зосереджені в південно-західній частині розкопу. Це - щелепа на відстані біля одного метру від центру вогнища, та ще декілька кісток на відстані від 1,80 до 2,20 м. Визначені кістки належали сугаку, благородному оленю та зайцю (табл. 2).

КУЛЬТУРНИЙ ШАР з-з залягав у верхній частині літологічного шару $F$, на 2 см вище другого прошарку білоглазки (рис. 5). Відділявся прошарком стерильного суглинку від культурного шару 3-4 потужністю біля 6 см, від культурного шару 3-2 в східній частині розкопу потужністю до 10 см, в західній - лише біля 2 см.

Культурний шар був представлений вогнищем у східній частині розкопу, в кв. 6и, 6й, 7и, 7й та кількома кістками тварин в західній частині (рис. 8). Вогнище пласке, підокругле в плані. Із сходу на захід воно простягалось на 1,00 м, 3 півночі на південь - на 1,20 м. Заповнення лінзи вогнища мало темно-темно-сірий, майже чорний колір, внаслідок надзвичайно великого вмісту деревинного вугілля. Проте, її максимальна потужність сягала всього лише 1 см. Прокал під лінзою також був вкрай незначний, всього декілька міліметрів, і простежувався не на всій площі. Вочевидь, вогнище було швидко перекрито глинистим седиментом та не зазнало ерозії. Для шару 3-3 визначена лише кістка - сугака (табл. 2).

КУЛьтУРний шАР 3-2. На більшій частині площі розкопу культурний шар знаходився у верхній частині жовтувато-брунатного глинистого суглинку літологічного шару F, безпосередньо під першим прошарком білоглазки, в ньому, або на 1-3 см вище. В крайній південно-західній частині розкопу, в кв. 10ж шар залягав в контактній зоні літологічних шарів $F$ та $E$ - в жовтуватобрунатному суглинку, але з невеликою домішкою щебеню. Від культурних шарів 3-3 та 3-1 він відділявся прошарками стерильного суглинку потужністю, відповідно, біля 7 та 4-8 см.

Центральним об'єктом культурного шару 3-2 (рис. 9) було вогнище в кв. 83. Вогнище пласке, неправильної овальної форми, розмірами по вісі південний захід — північний схід 1,25 м , по вісі північний захід - північний схід 1,10 м. Лінза вогнища була темно-сірого кольору, із значним вмістом шматочків деревинного вугілля. В центральній частині вона сягала максимальної потужності 4 см. На більшій частині, за виключенням лише північно-східної периферії, підстилалась прокалом брунатного кольору потужністю до 1 см.

На північний захід від вогнища, в кв. 8ж знаходились чотири невеликих скупчення вугілля підокруглої та підовальної форм. Одно з них мало діаметр біля 30 см та потужність 1-2 см, три інших були діаметром біля 10 см та потужністю до 1 см. Прокал під ними був відсутній. Зважаючи на розмір цих об'єктів, можна припустити, що вони являли собою не вогнища, а згорілі та зруйновані головні. Крім того, навколо вогнища, на відстані 0,501,00 м від його краю, культурний шар містив домішку невеликих вуглинок. Вона була більш помітною із західної, південної та східної сторін вогнища. Натомість із північної сторони ледь простежувалась.

В розташуванні археологічних матеріалів культурного шару 3-2 (рис. 9), представлених невеликим комплексом крем'яних виробів та кістками тварин, загалом простежується зв'язок із вогни- 
щем. В північно-східній та південно-західній його частинах знахідки були відсутні повністю. Практично всі вони знаходились в центральний частині розкопу. При цьому в розподілі артефактів простежуються декілька зон. Насамперед виділяється скупчення на захід від вогнища, в кв. 9ж та В кв. 93, де були знайдені практично всі крем'яні артефакти. Вони лежали або поруч, або лише в кількох десятках сантиметрів один від одного. Поруч знаходились також кістки тварин. Інші три скупчення розташовувались на південний захід, південь та схід від нього, на відстані від 1,20 до 1,50 м від його центру. Ще одне скупчення кісток було у 2,10 м на південь від вогнища. I, нарешті, щелепа та декілька кісток лежали безпосередньо в вуглистій лінзі вогнища.

Археологічний комплекс культурного шару 3-2, який складається 3 крем'яних виробів та кісток тварин, один із найвиразніших серед шарів юніту 3 і загалом подібний до комплексу шару 3-5/6. Крем'яний комплекс нараховує всього 11 виробів, проте, він надзвичайно показовий: більше половини з них мають вторинну обробку. Серед знарядь - мікроплатівка з притупленим кра$\epsilon м$, свідерський наконечник, сегмент та два різці. В якості заготівки для мікроплатівки з притупленим краєм (рис. 11: 3) використана мікроплатівка, одержана з одноплощинного нуклеусу, можливо, відтискним способом, судячи з регулярної огранки. Один край в неї оформлений стрімкою дорсальною ретушшю. Свідерський наконечник типовий, виготовлений на реберчастій платівці, сколотій з двоплощинного нуклеусу, із черешком. оформленим вентральною пласкою ретушшю та дорсальною стрімкою ретушшю (рис. 11: 10). Сегмент - невеликий, виготовлений на платівці, сколотій $з$ двоплощинного нуклеусу, оформлений стрімкою ретушшю (рис. 11: 2). За морфологічними ознаками він подібний до пізніх шанкобинських сегментів, проте відрізняється від них використанням в якості заготівки платівки, сколотої з двоплощинного нуклеусу, що є непритаманним для шан-кобинської культури. Різці - серединний та кутовий. Для серединного різця (рис. 11: 7) в якості заготівки використана масивна платівка, сколота з двоплощинного нуклеусу. Робочий край знаряддя неодноразово підправлявся. Кутовий різець, виготовлений на первинній платівці із рештками жовневої кірки (рис. 11: 9). Уламками якихось знарядь, скоріш за все, мікролітів, $є$ також уламок базальної частини платівки $з$ ретушшю 3 обох країв (рис. 11:4) та маленький уламок платівки з притуплюючою ретушшю (рис. 11: 5). Вироби без вторинної обробки представлені платівками (3 екз.) та лусками (2 екз.). Примітним $\epsilon$, що всі три платівки мають фасетки ретуші використання (рис. 11: 6, 8, 11). Особливо виразні вони в вели- кої платівки зі слідами реберчастого оформлення (рис. 11: 11). Кінчик цього виробу оброблений дрібною дорсальною ретушшю.

Крем'яний комплекс культурного шару 3-2 надзвичайно подібний до комплексу культурного шару 3-5/6. Перш за все, для обох комплексів характерним $\epsilon$ надзвичайно висока питома вага виробів із вторинною обробкою та використання в якості знарядь практично всіх крем'яних виробів - як із вторинною обробкою, так і без неї. За цими покажчиками комплекс культурного шару 3-2, безсумнівно, також був залишений невеликою мисливською групою при надзвичайно короткотерміновому заселенні гроту. По-друге, схожими $\epsilon$ техніко-морфологічні покажчики крем'яних виробів. Зокрема, більшість широких та середньо широких платівок в обох комплексах сколоті з двоплощинних нуклеусів (рис. 11: 7, 10, $16,13,20)$, натомість, для одержання мікроплатівок використовувався одноплощинний нуклеус, i одержані вони, скоріш за все, відтискним способом (рис. 11: 3, 4, 18). Практично ідентичними за морфологічними ознаками $\epsilon$ серединні різці обох комплексів - для їх виготовлення використані однакові платівчасті заготівки, одержані з двоплощинних нуклеусів, подібним $є$ оформлення робочої частини і, нарешті, збігаються навіть розміри.

Культурна атрибуція культурного шару 3-2, не зважаючи на його нечисленність, не являє складнощів. Типовий свідерський наконечник, платівки, одержані з двоплощинних нуклеусів i, до певної міри, серединний різець на платівці, дозволяють впевнено визначати його як свідерський. Не протирічить цьому і мікроплатівка з притупленим кра$\epsilon м$, одержана з одноплощинного нуклеусу, можливо, відтискним способом. Як відзначалось вище, при визначенні культурної приналежності культурного шару 3-5/6, Свідеру Криму були притаманні і пазові композитні наконечники метальної зброї з боковими вкладенями-мікроплатівками 3 притупленим краєм, і відтискна техніка.

Археозоологічні матеріали культурного шару 3-2 є найчисленнішими серед шарів юніту 3 (табл. 2) і різноманітні за видовим складом. Серед них визначені сугак, олень, ведмідь та заєць. Знайдена також кістка напівдорослого боривітра звичайного (Benecke 1999, s. 80).

КУЛЬтУРНИМ ШАРОМ 3-1 позначені темні відклади з невеликою домішкою деревинного дрібного вугілля, які залягали у самій верхній частині жовтувато-брунатного суглинку без щебеню літологічного шару F. Вони простежені лише в південній частині розкопу, в кв. 9й та 10й (рис. 10). На решті площі розкопу ці відклади були відсутні. Будь яких об'єктів в культурному шарі не зафіксовано. Лише на окремих ділянках простежувались нечіткі за обрисами скупчення деревинного вугілля. 
Достатня значна потужність відкладів, дуже малі розміри вуглинок та дисперсний характер їхнього залягання вказують на руйнацію культурного шару в давнину.

Археологічний комплекс культурного шару 3-1 складається лише із одного крем'яного виробу та окремих фрагментів кісток тварин. Вони знаходились поза межами поширення темних відкладів із домішкою вуглинок, але мали близьку із ними стратиграфічну позицію - за абсолютними глибинами та залягаючи лише на декілька сантиметрів нижче контакту літологічних шарів $\mathrm{E}$ та $\mathrm{F}$.

Крем'яний виріб шару - сколота з двоплощинного нуклеусу платівка з рештками жовневої кірки (рис. 11: 1). ІІї дистальний кінець обламаний, а проксимальний - ретушований. Площадка та відбивний горбик в неї зрізані вентральною ретушшю - пласкою 3 одного краю та похилою 3 другого. Додатково кінець загострений на одному 3 країв також дорсальною напівстрімкою ретушшю. Вентральна краєва ретуш $\epsilon$ також на одному з країв біля зламу. Скоріш за все, цей виріб $\epsilon$ незакінченим або недбало виготовленим та обламаним свідерським наконечником. Підставою для такого припущення $\epsilon$ подібна техніка виготовлення свідерського наконечника культурного шару 3-2 (рис. 11: 10). Отже, культурний шар 3-1, ймовірно, був залишений свідерцями. Окремі визначені кістки належать сугаку та оленю (табл. 2).

\section{дискУсія}

Для пам'ятки отримана серія радіовуглецевих дат в трьох лабораторіях: Геологічного Інституту АН СРСР (ГИН), лабораторії геохімії оточуючого середовища в Києві (Кi) та лабораторії Лейбниця університету Кіля в Німеччині (KIA), які наведені в таблиці 1. Культурні шари археологічного юніту 3 датуються часом від 11500 до 7600 років cal BP (табл. 1), тобто, $є$ ранньомезолітичними і припадають на ранній пребореал. Радіовуглецеві дати Шпан-Коби добре узгоджуються зі стратиграфічною позицією культурних шарів, для яких вони були отримані, корелюються між собою та відповідають загальній хроностратиграфії культурних шарів стоянки в контексті мезоліту Криму (Яневич 2019): у відповідності з радівуглецевим датуванням, вік культурних шарів юніта 3 (3-5/6, 3-4, 3-3, 3-2 та 3-1) та самого нижнього із юніта 2 (2-4/5) припадає, як відзначалось, на першу половину пребореалу, культурних шарів юніта 2 (2-2, 2-3 та 2-1) - на другу половину пребореалу, нижнього культурного шару юніта 1 (1-4/5) - на кінець бореалу, культурного шару 1-3 - на пре-атлантикум та культурного шару 1-1 - на початок атлантикуму. Відповідність культурних шарів означеним кліматичним періодам підтверджується також палінологічними дослідженнями розрізів стоянки (Gerasimenko et al. in press).
Незважаючи на надзвичайно малу кількість артефактів, знайдених в шарах археологічного юніту 3, їхня культурна атрибуція не викликає питань - вони залишені носіями свідерської культури. На це вказують, передусім, свідерські наконечники (рис. 11: 1, 10) та переважання платівок, які були зняті з двоплощинних нуклеусів (рис. 11: 7, 10, 12, 13, 16), притаманних цій культурі. Типову для свідерських памяток морфологію мають також серединні різці на платівчастих сколах (рис. 11: 7, 16). Звичайною для Свідеру Криму $\epsilon$ й мікроплатівка з притупленим краєм (рис. 11: 3) - подібні вироби знайдені в комплексі Сюрені II (нижній шар), Буран-Кая 3 (культурний шар 4) та Буран-Кая, навіс. Щодо свідерської приналежності культурних шарів юніту 3 заперечення може викликати лише характерний за морфологічними ознаками шан-кобинський сегмент (рис. 11: 2). Але він також виготовлений на платівці, одержаній із двоплощинного нуклеуса, та схожі сегменти $\epsilon$ в багатьох свідерських кримських комплексах. Загалом, крем'яні комплекси культурних шарів юніта 3 Шпан-Коби мають численні аналогії серед комплексів інших свідерських памяток Криму (Яневич 2010).

На півострові на сьогодні відомо одинадцять розкопаних пам'яток та місцезнаходжень свідерської культури (Яневич 2010). Частина з них стратифіковані, з виразними комплексами крем'яних виробів. Утім на більшості знайдені нечисленні, або поодинокі свідерські знаряддя. Свідерські стоянки знаходяться виключно в Гірському Криму (рис. 2).

Переважна більшість свідерських пам'яток розташована в зоні Другого пасма Кримських гір, виключно в навісах. Серед них культурний шар, який залягав в чітких стратиграфічних умовах, мали лише три - Сюрень II (нижній шар) (Бонч-Осмоловский 1934; Векилова 1957; 1961; 1966; Коен 1996; Janevic 1999), Буран-Кая 3 (шар 4) (Janevic 1999; Яневич 2010), Буран-Кая 4 (шар 3D-1). На решті пам'яток свідерський культурний шар був складовою палімпсесту, або ж були знайдені лише поодинокі свідерські знаряддя. Це - БуранКая, навіс (Бадер 1976), Фатьма-Коба (шар 5), ШанКоба (шари 4 та 3), Мурзак-Коба, Шайтан-Коба (Великий грот) (Векилова 1966; Залізняк, Яневич 1987; Janevic 1999).

На плоскогір'ях Першого пасма Кримських (яйлах) свідерські пам'ятки нечисленні. Їх лише три. Із них дві - Су-Ат III та Ала-Чук, мають зруйновані культурні шари (Колосов 1957; Залізняк, Яневич 1987; Janevic 1999). Стратифікова свідерська стоянка на яйлі лише одна - Шпан-Коба (шари юніту 3).

Слід відзначити, що свідерці, які перебували в Криму в другій половині молодого дріасу та пребореалі, були першими, хто почав освоювати яйли 
Першого Пасма Кримських гір у фінальному палеоліті та ранньому мезоліті. Це викликає подив, бо в зоні Другого пасма, в передгір'ях, відомо багато стоянок шан-кобинськї культури (рис. 2), яка набагато передувала свідерській, існувала разом із нею та пізніше (Яневич 2019). Але тим не менш, на сьогодні на яйлі маємо лише три фінальнопалеолітичні та/або ранньомезолітичні пам'ятки, при чому всі вони свідерські. У зв'язку із цим, свідерські культурні шари юніту 3 Шпан-Коби, які мають виключну збереженість, та для яких проведені радіовуглецеве датування, палінологічні та археозоологічні дослідження, набувають особливого значення як для з'ясування освоєння яйл в ранньому мезоліті, так і для уяви про використання в цей час скельних жител зокрема.

Хронологічно культурні шари археологічного юніту 3 гроту Шпан-Коби, як відзначалося вище, припадають на ранній пребореал. Згідно з проведеними нещодавно палеоботанічними та палеокліматичними дослідженнями споро-пилкових спектрів відкладів гроту, «Довгоруківська яйла

Табл. 1. Радіовуглецеві дати стоянки Шпан-Коба (за Gerasimenko et al. in press).

Table 1. Radiocarbon dates of the Shpan-Koba site (after Gerasimenko et al. in press).

\begin{tabular}{|c|c|c|c|c|c|c|c|}
\hline Пам'ятка & Шар & $\begin{array}{l}\text { Номер } \\
\text { зразка }\end{array}$ & ${ }^{14} \mathrm{C} \mathrm{BP}$ & $\begin{array}{l}\text { Вік.діапазон, } 2 \sigma \\
\text { похибка, cal ВP }\end{array}$ & $\begin{array}{c}\text { Середній } \\
\text { калібрований } \\
\text { вік, cal BP }\end{array}$ & Культура & Посилання \\
\hline Шпан-Коба & $1-1$ & Ki-5822 & $6,780 \pm 40$ & $7,679-7,577$ & 7,628 & Мурзак-Коба & Зайцева та ін. 1997 \\
\hline Шпан-Коба & $1-3$ & Ki-5821 & $7,600 \pm 45$ & $8,480-8,381$ & 8,431 & Мурзак-Коба & Зайцева та ін. 1997 \\
\hline Шпан-Коба & $1-5$ & ГИН-6277 & $8,240 \pm 150$ & $9,530-8,850$ & 9,190 & Шпанська & Яневич 2010 \\
\hline Шпан-Коба & $2-1$ & KIA-3589 & $9,560 \pm 50$ & $11,108-10,711$ & 10,910 & Шпанська & Яневич 2010 \\
\hline Шпан-Коба & $2-3$ & ГИН-5276 & $9,150 \pm 150$ & $10,748-9,888$ & 10,318 & Шпанська & Яневич 2010 \\
\hline Шпан-Коба & $2-4$ & KIA-3688 & $9,790 \pm 50$ & $11,277-11,126$ & 11,202 & Свідерська & Яневич 2010 \\
\hline Шпан-Коба & $2-5$ & KIA-3687 & $9,730 \pm 50$ & $11,244-11,079$ & 11,162 & Свідерська & Яневич 2010 \\
\hline Шпан-Коба & $3-2$ & KIA-3686 & $9,760 \pm 60$ & $11,273-11,075$ & 11,174 & Свідерська & Яневич 2010 \\
\hline Шпан-Коба & $3-2$ & Ki-5824 & $9,890 \pm 80$ & $11,624-11,180$ & 11,402 & Свідерська & Яневич 2010 \\
\hline Шпан-Коба & 3-4 & KIA-3685 & $9,930 \pm 60$ & $11,615-11,223$ & 11,419 & Свідерська & Яневич 2010 \\
\hline Шпан-Коба & $3-5 / 6$ & KIA-3684 & $9,840 \pm 50$ & $11,354-11,182$ & 11,268 & Свідерська & Яневич 2010 \\
\hline Шпан-Коба & $3-5 / 6$ & KIA-3683 & $9,940 \pm 50$ & $11,505-11,237$ & 11,371 & Свідерська & Яневич 2010 \\
\hline
\end{tabular}

Табл. 2. Шпан-Коба, розкопки 1989 р. Кількість кісток (NISP) для визначаємих видів по культурних шарах юніту 3 (за Benecke 2000, p. 111, Tabl. 2).

Table 2. Shpan-Koba, 1989 excavations. The number of bones (NISP) for species in the cultural layers of the unit 3 (after Benecke 2000, p. 111, Tabl. 2).

\begin{tabular}{|c|c|c|c|c|c|}
\hline Група/Види & $3-5 / 6$ & $3-4$ & $3-3$ & $3-2$ & 3-1 \\
\hline \multicolumn{6}{|l|}{ І. Ссавці } \\
\hline Заєць сірий (Lepus europaeus) & 2 & 1 & - & 1 & - \\
\hline Хом'як (Cricetus cricetus) & 3 & - & - & - & - \\
\hline Лисиця звичайна (Vulpes vulpes) & 1 & - & - & - & - \\
\hline Ведмідь бурий (Ursus arctos) & 8 & - & - & 5 & - \\
\hline Кінь дикий (Equus ferus) & 1 & - & - & - & - \\
\hline Олень благородний (Cervus elaphus) & 2 & 6 & - & 10 & 1 \\
\hline Сугак (Saiga tatarica) & 9 & 2 & 1 & 12 & 2 \\
\hline \multicolumn{6}{|l|}{ II. Птахи } \\
\hline Боривітер звичайний (Falco tinnunculus) & - & - & - & 1 & - \\
\hline \multicolumn{6}{|l|}{ III. Невизначені } \\
\hline Група 1 (олень та ін.) & 17 & - & 1 & 8 & - \\
\hline Група 2 (свиня та ін.) & 61 & - & 2 & 142 & 2 \\
\hline Група 3 (заєць та ін.) & - & 3 & - & - & - \\
\hline Невизначаємі & - & 1 & 1 & - & - \\
\hline ВСьОГО & 106 & 13 & 5 & 179 & 5 \\
\hline
\end{tabular}


біля стоянки Шпан-Коба на самому початку раннього пребореалу (археологічний шар 3-3) була вкрита мезофітним степом із різноманітним різнотрав'ям (із переважанням цикорієвих) та айстровими. Ксерофітні трави були майже відсутні; зустрічались лише декілька типових пізньольодовикових флорістичних елементів (Artemisia sp. та Ephedra distachya). Сосна з невеликою домішкою ялівця та берези росла на більш високих схилах гір, верба та папороть - в долині Чау-Кетау. Клімат був набагато прохолоднішим, ніж зараз, але, судячи з відкладів у печері (зникнення крупних кутоватих блоків вапняку та дрібного уламкового матеріалу), він був більш м'який, ніж під час попереднього стадіалу льодовиків'я в Криму.» (Gerasimenko et al. in press). До наведеної реконструкції рослинності зауважимо, що на сьогодні кліматичні умови в районі стоянки набагато м'якіші ніж в ранньому пребореалі - вона знаходиться на межі степів яйли та букових лісів, а сосна та береза відсутні зовсім.

Фауністичні матеріали з культурних шарів археологічного юніту 3 Шпан-Коби нечисленні, але достатньо показові. Результати їх досліджень були опубліковані $\mathrm{H}$. Бенеке в кількох працях (Benecke 1999; 2000) (табл. 2). Примітним є склад крупних ссавців - у переважній більшості шарів юніту 3 знайдені кістки сугака, благородного оленя та бурого ведмедя. Складається враження, що саме ці три види тварин були метою мисливських експедицій свідерців на Суботкан-яйлу у ранньому пребореалі.

Сугак (Saiga tatarica) знайдений у всіх без винятку культурних шарах юніта 3, але, водночас, повністю відсутній в пізніших шарах (табл. 2). За даними Н. Бенеке, на стоянці більшість кісток цього виду належить дорослим особинам (Benecke 2000 , р. 114). Цей вид, притаманний більше палеоліту, утім, зустрічається на фінальнопалеолітичних та ранньомезолітичних стоянках Другого пасма (Векилова 1971, с. 125, 126, табл. 3). Сугак Шпан-Коби, безумовно, літній мігрант із степів Рівнинного Криму - через високий сніговий покрив на яйлі взимку він не зміг би вижити. Один із шляхів його міграції на яйлу пролягав по долині р. Бурульча, в яку впадає балка Чау-Кетау із розташованою в її верхів'ях Шпан-Кобою. Зокрема, численні рештки сугака знайдені в свідерському шарі Буран-Каї 3, розташованій в долині р. Бурульча в зоні Другого пасма Кримських гір (Lanoe, Pean, Yanevich, 2015).

Другий поширений для раннього мезоліту Шпан-Коби вид благородний олень (Cervus elaphus). Він також представлений у всіх культурних шарах юніту 3, за виключенням лише шару 3-3 (табл. 2). Олень $\epsilon$ одним із представників «мисливської тріади» фінального палеоліту, мезоліту та неоліту Криму: благородного оленя, кабана та козулі (див.: Векилова 1971, с. 125, 126, табл. 3). При цьому, для фінального палеоліту та раннього мезоліту притаманне домінування саме благородного оленя. Подібне спостерігається й для Шпан-Коби: олень $\epsilon$ практично у всіх ранньомезолітичних шарах, натомість інші два члени «тріади» - кабан та козуля, поки що відсутні повністю. Домінуючим кабан в Шпан-Кобі стає лише в середньому та пізньому мезоліті (Benecke 2000, p. 111, Tabl. 2). Такий видовий розподіл мисливської здобичі в Шпан-Кобі обумовлений насамперед природними причинами - сприятливими для благородного оленя ранньопребореальними ландшафтами Гірського Криму та яйли зокрема. За остеометричними даними олені на стоянці належали до крупних екземплярів, а один із них «... вирізнявся надзвичайно великими розмірами, які рідко зустрічаються у первісності» (Benecke 1999, s. 78). Олені були представлені кістками всіх частин тіла напівдорослих та дорослих особин. На думку Н. Бенеке, комплектність туш тварин свідчить, що олені були принесені в грот та розроблені на стоянці (Benecke 2000, р. 114).

Третім важливим об'єктом полювання ранньомезолітичних мешканців Шпан-Коби був бурий ведмідь (Ursus arctos). Він достатньо рідкий для мезоліту Криму вид, причому кістки цього звіра знайдені здебільше в ранньомезолітичних шарах (Векилова 1971, с. 125, 126, Табл. 3). У Шпан-Кобі вони також $\epsilon$ у шарах 3-5/6 та 3-2 (табл. 2), але при цьому повністю відсутні в середньому та пізньому мезоліті. Решки ведмедя представлені ребрами, нижньою щелепою та поодинокими фрагментами кісток кінцівок. Деякі із них мають cut marks - сліди розробки туші (Benecke 2000, p. 111, Tabl. 2).

Достатньо численними в культурних шарах юніту $3 \in$ рештки зайця, а в шарі 3-5/6 знайдені також рештки хом'яка та рисі (табл. 2), хоча вони навряд чи були скільки-небудь суттєвими в мисливській здобичі ранньомезолітичних шпанкобинців. Цікавою $\epsilon$ знахідка решток коня (Equus ferus) в шарі 3-5/6 - тварини, яка подекуди зустрічається в фінальнопалеолітичних та ранньомезолітичних шарах стоянок Другого пасма (Векилова 1971 , с. 125, 126, табл. 3).

На багатьох кістках виявлені сліди розбивання та нарізки - свідчення оббілування, розробки та споживання туш впольованих тварин (Benecke 1999; 2000). При цьому, для з'ясування характеру ранньомезолітичних помешкань в Шпан-Кобі показовою $\epsilon$ середня вага кісток по окремих шарах стоянки - в усіх культурних шарах юніта 3 вони були в декілька разів крупніші, ніж в середньо - та пізньомезолітичних (Benecke 2000, p. 112, Tabl. 4). Це, безсумнівно, демонструє меншу інтенсивність використання впольованої мисливської здобичі, 
а також тривалість та активність заселення гроту загалом. За археозоологічними даними - щелепами оленів, встановлений час заселення для культурного шару 3-5/6 Шпан-Коби. Одна щелепа вказує на час з квітня по червень, а інша з червня по серпень (Benecke 2000, p. 117, Fig. 8). Решта культурних шарів також, безумовно, утворилась під час відвідин гроту в теплу пору року - взимку високий сніжний покрив яйл майже унеможливлює існування на них копитних тварин.

Отже, під час утворення культурних шарів юніту 3 гроту Шпан-Коба, навколо розташовувались мезофітні степи. Присутність пилку сосни та берези в відкладах вказують, що клімат був набагато прохолодніший за сучасний. Метою перебування свідерців на яйлі, судячи з археозоологічних матеріалів, було полювання на сугака, благородного оленя та бурого ведмедя, а час їх перебування в гроті ШпанКоба припадає на теплу пору року - весну та літо.

Грот Шпан-Коба поступався своїми характеристиками житла перед класичними для Криму сухими, орієнтованими на південь скельними навісами, в яких розташовані пам'ятки кам'яної доби Криму в зоні Другого пасма Кримських гір. Він, нагадаємо, має карстове походження і являє собою устя печери. В наш час його задня частина, яка являє собою початок карстової печери, мокра навіть в сухі літні місяці. Вогкими були під час розкопок й відклади літологічного шару $F$, в яких залягали культурні шари юніту 3 - жовтувато-бурий глинистий суглинок без щебеню. Вони утворились, судячи із їх складу, ґенези гроту та кліматичних умов, в результаті виносу глинистого седименту із карстової печери та/або його промивання по дрібним тріщинам піддашшя гроту. Це припущення підтверджується швидкою седиментацією під час утворення літологічного шару F. Його майже метрова товща відклалася за радіовуглецевими датами менше ніж за тисячу років (табл. 1). Очевидно, винос глинистого седименту в окремі періоди був достатньо інтенсивним. Наприклад, вогнища №2 та №3 культурного шару 3-5/6, які були залишені, судячи із їх розташування одне над одним, тією ж самою групою свідерської людності, виявились вже розділеними стерильним прошарком в декілька сантиметрів. Отже, грот в ранньому пребореалі, скоріш за все, був вогкий і не надто комфортний для мешкання.

У цьому зв'язку примітно, що в літологічному шарі D спостерігається перерва в заселенні гроту Шан-Коба. Цей шар схожий за складом до літологічного шару F. Його також утворюють винесені водою глинисті відклади без вапнякового уламкового матеріалу. Але літологічний шар D за радівуглецевими датами, утворився під час потепління та зволоження бореалу (табл. 1). Кліматичні умови цього періоду були набагато м'якішими ніж клімат раннього пребореалу (Gerasimenko et al. in press), і шпанське населення, яке на цей час вже змінило свідерців, скоріш за все, надавало перевагу відкритим поселенням аніж вогкому гроту.

Свідерці на яйлі мали також поселення просто неба, наприклад, Су-Ат та Ала-Чук, які розташовані на сідловинах, біля витоків річок в південній частині Карабі-яйли. Але, у свідерців, які залишили ці стоянки, не було іншого вибору - розташованих поблизу скельних прихисток. Натомість, грот Шпан-Коба, навіть незважаючи на його вірогідну вогкість, в ранньому пребореалі був, вочевидь, гідною альтернативою помешканню на відкритому місці. До того ж, він розташований в орієнтованому на південний схід скельному обриві довжиною біля 50 метрів і додатково прикритий 3 півночі горою Калам-Баїр. Нарешті, Шпан-Коба це єдиний скельний прихисток в північній частині Суботкан-яйли, який підходив за своїми параметрами для житла.

Культурні шари юніту 3 дозволяють скласти уяву про використання гроту Шпан-Коба в ранньому мезоліті у якості помешкання. Передусім, привертає увагу, що всі ранньомезолітичні культурні шари були добре представлені в центральній та північно-східній частинах гроту - саме тут розташовувались вогнища, більшість артефактів та була інтенсивнішою вуглиста домішка в седименті окремих культурних шарів. Принагідно відзначимо, що подібна планіграфія була притаманна й пізнішим культурним шарам - середнього та раннього мезоліту. Певною мірою це пояснюється конфігурацією гроту Шпан-Коба в південно-західній своїй частині, до якої спостерігалось виклинювання культурних шарів, він був нижче та не такий глибокий. Але основним чинником більш інтенсивного заселення східної та центральної частини гроту була їхня краща інсоляція зранку та в першій половині дня, а отже і краще прогрівання помешкання, яке була особливо цінним після нічного холоду.

Зони активності в культурних шарах простежувались насамперед за вогнищами, крем'яними артефактами, кістками тварин та, в меншій мірі, домішками вуглинок в седименті. Внаслідок нерегулярного заселення гроту, шари не зазнали антропогенної руйнації, тобто, утворення палімпсесту, який $є$ основною проблемою дослідження скельних пам'яток первісності. Виключенням $\epsilon$ лише культурний шар 3-5/6, який утворився, без сумніву, при багаторазовому заселенні. Серед суттєвих природних чинників впливу на тафономію культурних шарів Шпан-Коби були, безумовно, хижаки, які могли з'їсти, або винести частину кісок, але кістки, які були знайдені, навряд чи зазнали суттєвих переміщень, а отже відображають давню планіграфію помешкань. 
Вогнища розкопані практично у всіх культурних шарах, за винятком хіба що культурного шару 3-1, де воно було зруйноване. Вони були надзвичайно подібними: одного типу — пласкі, із лінзою потужністю 1-3 см та розмірами 1,00-1,20 м. Прокал спостерігався для більшості вогнищ, він був темно-червоного або коричневого кольору і сягав максимальної потужності 2 см. Будь які ознаки чищення вогнищ для повторного використання, тобто викидання золи та вугілля, відсутні. Поза вогнищами незначна вуглиста домішка простежувалась в культурному шарі 3-5/6 на більшій частині розкопу і в культурних шарах 3-4 та 3-2 навколо них. Але у всіх випадках, судячи із невеликого його вмісту, йдеться про ненавмисний рознос вугілля або ж про зруйновані головні для обігріву. Очевидно, як головні для обігріву слід інтерпретувати в шарі 3-2 вуглисті плями розмірами від 10 до 30 см без прокалу під ними на захід від вогнища (рис. 9). Отже, за всіма ознаками, вогнища функціонували, скоріш за все, дуже короткий час - один або декілька днів.

Гарна збереженість культурних шарів археологічного юніту 3 дозволяє простежити певні закономірності в розташуванні знайдених у них артефактів - вони були пов'язані з вогнищами, й характер їхнього розташування загалом відповідає класичній «Drop-Toss model» («моделі падіння-кидання») Л. Бінфорда (1978; 1983). Нечисленність археологічних матеріалів Шпан-Коби не дозволяє провести докладний drop-toss aналіз, який зараз значно вдосконалений та широко використовується при дослідженні стоянок, починаючи із середнього та пізнього палеоліту (див.: Henry 2012; Кротова 2013, с. 267-276 та ін.). Але навіть без статистичного вивчення розподілу артефактів, за наведеною вище планіграфією у культурних шарах Шпан-Коби спостерігаються основні ознаки цієї моделі. Насамперед, знахідки у всіх культурних шарах були пов'язані з вогнищами. По-друге, найбільша площа поширення знахідок, яка була зафіксована в культурному шарі 3-5/6, не перевищує 4 x 4 м (рис. 6). Це дещо менше, ніж максимальна площа активності навколо одного вогнища за Л. Бінфордом - 5 × 6 м (Binford 1983 , с. 151 - 154, Fig. 86, 88, 89). У решті культурних шарів розмір площі зі знахідками був ще менший. Нарешті, у всіх культурних шарах, за виключенням лише шару 3-5/6, подібно до «drop-toss model», навколо вогнищ із західної, південної та східної сторін простежувались три концентричні зони: 1) без знахідок або, в одному випадку - в шарі 3-2, із крем'яними виробами; 2) з дрібними кістками та крем'яними артефактами (зона падіння); 3) із крупнішими кістками (зона кидання).

Найбільш показовими для з'ясування використання житлового простору гроту Шпан-Коба в ранньому мезоліті є культурні шари 3-2 та 3-4. В розташуванні археологічних матеріалів культурного шару 3-2 (рис. 9) простежуються декілька зон. Перша зона була на захід від вогнища, безпосередньо біля нього. Тут знаходились практично всі крем'яні вироби культурного шару й фрагменти кісток, переважно дрібних. Примітним $\epsilon$ розташування та склад крем'яних артефактів. Вони лежали або поруч, або лише в кількох десятках сантиметрів один від одного, тобто, в зоні досяжності людини, що сидить. Представлені крем'яні артефакти наконечниками метального озброєння обламаним свідерським наконечником (рис. 11: 10) та сегментом (рис. 11: 2), або ж знаряддями 3 виготовлення та ремонту озброєння - різцями (рис. 11: 7, 9) та крупною платівкою (рис. 11: 11). Складається враження, що безпосередньо на південний захід від вогнища знаходилось місце мисливця з ремонту зброї для полювання.

Інші скупчення знахідок в шарі 3-2 складались виключно з кісток. Вони розташовувались на південь та південний схід від вогнища. Два з них знаходились на відстані від 1,20 до 2,00 м від його центру, що, відповідно до класичної етнографічної drop-toss моделі (Binford 1978) та її археологічних варіантів (див.: Henry 2012), дозволяє інтерпретувати ці скупчення кісток, як зони падіння. Ще два скупчення кісток знаходились на південь від вогнища, на відстані 2,00-2,70 м від його центру, за цими покажчиками вони відповідають зоні кидання. Цікаво, що в північної периферії лінзи вогнища лежали щелепа та великий уламок кістки, а ще далі, поза його межами - ребро. За своїм розташуванням із підвітряної сторони вогнища, ці кістки нагадують передню зону кидання за Л. Бінфордом (Binford 1983, p. 153, fig. 89). Розташування знахідок шару 3-2, як мінімум на половині периметру вогнища, дозволяє припускати, відповідно до drop-toss моделі, що навколо нього розташовувалось до чотирьох чоловік (див.: Binford 1983, p. 153, fig. 89; Henry 2012, p. 253, fig. 7). Очевидно, помешкання культурного шару 3-2 в гроті було короткотерміновим, але, водночас, одним із найтриваліших у порівнянні з іншими. На це вказує не лише наявність крем'яних виробів, але й невелика вуглиста домішка в седименті навколо вогнища та найбільша кількість кісток мисливської здобичі серед культурних шарів юніту, які були також різноманітні за складом: заєць, ведмідь, олень, сугак (табл. 2).

Культурний шар 3-4 мав майже ідеальні параметри drop-toss моделі. Його центральним об'єктом було вогнище. На відстані 1,0 м від центра вогнища лежала щелепа (зона падіння). Далі, на відстані від 1,0 до 1,8 м - порожній простір (зона сидіння). Ще далі, від 1,8 до 2,30 м від центра вогнища купка кісток (зона кидання) (рис. 7). Складається враження, що культурний шар залишений однією 
людиною. Але в шарі знайдені кістки зайця, благородного оленя та сугака (табл. 2), а це дещо забагато для здобичі та подальшого споживання або ж транспортування однією людиною. Отже, $є$ підстави вважати, що шар залишений кількома мисливцями під час короткочасного заселення гроту для відпочинку та розробки здобичі.

Подібною, але менш показовою є просторова організація помешкання, яке репрезентує культурний шару 3-3. Шар складався з вогнища та купки кісток у 3,0 м на захід від його центру (рис. 8). При цьому вуглиста лінза вогнища та прокал під ним були значно меншими, ніж у культурному шарі 3-4, а кістки належали лише сугаку (табл. 2). Тобто і цей шар утворився під час вкрай нетривалих відвідин гроту одним або кількома мисливцями.

Вкрай невиразним $є$ помешкання культурного шару 3-1 (рис. 10). Але й у ньому простежуються ознаки drop-toss моделі. Вуглистий седимент та невеликі нечітки скупчення деревинного вугілля В кв. 9й та 10й можна інтерпретувати як зруйноване вогнище, декілька кісток та уламок свідерського наконечника на захід, очевидно, $\epsilon$ зоною падіння, а купка кісток в кв. 103 - зоною кидання. Археозоологічні матеріали, не зважаючи на нечисленність, представлені рештками сугака та оленя (табл. 2). А отже, слід припускати, що культурний шар 3-1, подібно до культурного шару 3-4, залишений не одним, а кількома мисливцями.

Культурний шар 3-5/6 вирізняється серед інших (рис. 6). Він, безумовно, утворився під час декількох відвідин гроту. На це вказують кількість вогнищ, їхня різна стратиграфічна позиція відносно одне одного, характер поширення седименту 3 домішками вуглинок тощо. Отже, шар являє собою класичний палімпсест, що ускладнює розуміння структур окремих його помешкань. Тим не менше, в його планіграфії простежуються певні особливості.

Центральними об'єктами просторової організації різночасових помешкань культурного шару 3-5/6, безумовно, були вогнища. Із невеликим вогнищем №1, очевидно, пов'язані дрібні кістки на північ та на південь від нього. Решта ж знахідок шару просторово відносяться до вогнищ №2 та №3, які співпадають в плані, але відділені одне від одного кількома сантиметрами седименту. Тобто, ці вогнища, вірогідно, залишені однією групою людей але із часовим інтервалом в один або декілька років. 3 огляду на це, їх можна розглядати як одну структурну одиницю організації житлового простору. Примітно, що на захід та на південь від них можна спостерігати вільну від знахідок смугу на відстані від 50-80 см периферії вогнищ, подібно до просторової організації інших культурних шарів. Але, водночас, самі знахідки як кістки, так і крем'яні вироби, були більш-менш рівномірно розподілені на поверхні шару. Вони розташовувались зі всіх сторін вогнищ, хоча, в переважній більшості, на захід та південь від них. Подібне розташування артефактів, без вираженої toss zone $\epsilon$ покажчиком існування якоїсь штучної загородки (Binford 1983, 144-192), що корелюється із насиченістю та поширенням вуглистого седименту в культурному шарі. Отже, помешкання в культурному шарі 3-5/6, з огляду на надзвичайну різноманітність складу мисливської здобичі (табл. 2), присутність крем'яного комплексу та можливу житлову споруду, також були короткотерміновими, але тривалішими, в порівнянні 3 іншими культурними шарами.

У розташуванні знахідок в культурних шарах юніту 3 простежується ще одна особливість - у шарах 3-4, 3-3, 3-2 та 3-1 вони знаходились виключно на захід, південь, та, в одному випадку (шар 3-2), на південний схід від вогнищ. За спостереженнями Л. Бінфорда та інших археологів, накопичення артефактів для діючих вогнищ, за відсутності житлової конструкції, відбувається лише з одного, навітряного боку, тобто, $є$ «асиметричним» по відношенню до нього (Binford 1978; 1983; Henry 2012). Таким чином, грот Шпан-Коба в ранньому мезоліті, очевидно, використовувався, переважно, як природне укриття без якихось додаткових облаштувань. Принаймні, розкопана лише одна безумовно штучна споруда - стінка з каменів у культурному шарі 3-5/6, яка, скоріш за все, була конструктивною частиною розташованих у ньому вогнищ №2 та №3 (рис. 6). Крім того, «симетричне» розташування знахідок по відношенню до вогнищ, відсутність зони кидання, характер поширення артефактів та седименту культурного шару $з$ вуглистими домішками, як відзначалось вище, також дають підстави припускати існування всередині гроту, під час утворення культурного шару 3-5/6, якоїсь житлової конструкції, можливо, вітрового заслону або ж куреня 3 гілок. Подібні легкі конструкції з рослинних матеріалів відомі не лише з етнографії, але й з археології, починаючи, щонайменше, із середнього палеоліту. Зокрема, вітровий заслон із гілок був простежений за фітолітами в скельному навісі Тор Фарадж, на півдні Йорданії (Henry 2012). Цікавим для з'ясування присутності штучних споруд $є$ також культурний шар 3-2. 3 однієї сторони, його структура $\epsilon$ типовою для «drop-toss» моделі з «асиметричним» розташуванням артефактів навколо вогнища, про що йшлося вище. Водночас привертає увагу, що зона кидання $\epsilon$ лише в південно-східному секторі від вогнища і відсутня в південно-західному. Поєднання цих двох ознак дозволяє припустити існування в помешканні культурного шару 3-2 вітрового заслону, який лише частково прикривав його із південного заходу (рис. 9). 
За розташуванням знахідок по відношенню до вогнищ в культурних шарах 3-4, 3-3, 3-2 та 3-1 $\epsilon$ очевидним, що під час утворення вогнищ культурних шарів юніту 3 панував вітер південного напрямку, або інакше кажучи, вітер, який дув вздовж задньої стінки грота і скельної стінки, в якій він розташований. 3 середини червня до середини серпня, себто, в період ранньомезолітичного заселення гроту Шпан-Коба за археозоологічними даними, на яйлах домінують західні та північно-західні вітри тривалістю до 300 - 350 годин на місяць (Подгородецкий 1988). Виходячи 3 цього, пануючий південний вітер для вогнищ шарів юніту 3 ніяк не може бути пов'язаний з їхньою сезонністю. На наш погляд, цей напрямок вітру $\epsilon$ добовим катабатичним повітряним потоком, який утворювався ввечері та вночі при охолодженні повітря відкритого плато Суботкан-яйли, та стікав із верхів"їв по тальвегу балки Чау-Кетау, в якій розташована стоянка. Принагідно зауважимо, що холодний нічний вітер дошкуляв і нам у таборі під скельною стінкою біля гроту під час розкопок, які провадились саме в липні.

Завершуючи розгляд просторової організації помешкань культурних шарів юніта 3 Шпан-Коби, можна зробити наступні висновки. Культурні шари надзвичайно подібні між собою. Вони відображають вкрай короткотермінові заселення гроту. Грот, очевидно, використовувався, переважно, без будь-яких додаткових житлових конструкцій, за виключенням лише помешкання культурного шару 3-5/6, для якого можна припускати вітровий заслін або курінь, та культурного шару 3-2 з вірогідним вітровим заслоном. Ранньомезолітичні помешкання в гроті залишені невеликими групами людей. Наявність лише одного вогнища в кожному 3 культурних шарів, розташування артефактів та площа їх поширення дають підстави припускати, що чисельність груп у будь якому разі не перевищувала чотирьох або п'яти чоловік.

На короткотерміновість ранньомезолітичних помешкань Шпан-Коби вказують також археологічні матеріали. Зокрема, кістки в культурних шарах юніту 3, як відзначалось вище, нечисленні, і в декілька разів крупніші, ніж в пізніших середньо - та пізньомезолітичних шарах (Benecke 2000, p. 112, tabl. 4), що є ознакою меншої інтенсивності використання впольованої мисливської здобичі. Крем'яний інвентар також вкрай нечисленний і знайдений лише в трьох шарах із п'яти. Примітним $\epsilon$ те, що біля половини крем'яного комплексу складають вироби зі вторинною обробкою. Це, насамперед, наконечники стріл - свідерські наконечники, сегмент та платівки 3 притупленим краєм, або знаряддя з ремонту мисливського спорядження - різці, скребачка (?). В якості знарядь використовувалась і решта крем'яних виробів - всі платівки та відщеп мають сліди макрозносу у вигляді нерегулярних фасеток ретуші. Відсутність будь-яких технологічних сколів та крем'яних лусок дозволяє припускати, що всі кремяні вироби були принесені в грот і покинуті після ремонту мисливського спорядження або розробки впольованих тварин. Водночас, цікавою $\epsilon$ присутність в крем'яному комплексі спрацьованого нуклеусу. Очевидно, «експедиційний» мисливський крем'яний набір передбачав також оперативне отримання заготовок у разі крайньої потреби. Отже, за планіграфічними та археологічними даними, ранньомезолітичні помешкання гроту Шпан-Коба залишені невеликими (від 1 до 5 чоловік) групами свідерців під час вкрай нетривалих його заселень з метою відпочинку, оббілування та розробки здобичі, ремонту мисливського спорядження тощо.

Короткотерміновий експедиційний характер ранньомезолітичних помешкань Шпан-Коби стає ще більш виразним, якщо порівняти їх із середньо - та пізньомезолітичними поселеннями цього ж гроту. Господарська стратегія використання яйл та гроту Шпан-Коба в середньому та пізньому мезоліті суттєво відрізнялась від ранньомезолітичної. Середньомезолітичні культурні шари на пам'ятці залишені носіями шпанської культури в пребореалі та пізньому бореалу (Яневич 1993), а пізньомезолітичні - в пре-атлантикумі та атлантикумі (табл. 1). На відміну від ранньомезолітичних шарів юніту 3, всі вони являють собою «палімпсести», які утворились в результаті багаторазових і частих заселень: вогнища в них часом накладаються одне на одне, а відклади на значній площі розкопу мали темне забарвлення та містили велику домішку дрібного вугілля та золи, стерильні прошарки не простежувались. Артефакти в середньо - та пізньомезолітичних культурних шарах Шпан-Коби численні, у всіх без винятку шарах вони представлені як кістками тварин, так і крем'яними виробами. Відрізняється, в порівнянні з нижніми ранньомезолітичними шарами, i склад крем'яних комплексів: абсолютна більшість їх припадає на продукти первинного розколювання кременю - платівки, відщепи, луски та технологічні сколи, що вказує на повний цикл розколювання кременю й відносно тривале мешкання, а не суто мисливську експедицію 3 «кишеньковим» набором знарядь. Усі ці характеристики верхніх культурних шарів Шпан-Коби свідчать про зміну господарської стратегії використання кримського високогір'я. В середньому та пізньому мезоліті поселення на яйлі стають частішими та тривалішими. На цей час припадає формування стійкого річного господарського циклу мезоліту та неоліту Криму: використання природних ресурсів кримських передгір'їв в холодну пору року і яйл - в 
теплу (Яневич 1990). Такі переміни були результатом загального потепління й зміни рослинності та фауністичного комплексу. Внаслідок цього умови для літніх міграцій на яйлу стали більш сприятливими. Ще однією причиною інтенсивнішого використання цієї зони Гірського Криму носіями шпанської та, особливо, мурзак-кобинської культур, був, очевидно, демографічний тиск, який змушував використовувати максимум доступних харчових ресурсів гірської зони як за їхнім складом (крупні ссавці, птахи, равлики та ін.), так і за територією поширення.

\section{ВИСНОВКИ}

Грот Шпан-Коба на сьогодні $\epsilon$ єдиною стратифікованою пам'яткою мезоліту та неоліту на Першому пасмі Кримських гір (яйлах). Нижні культурні шари стоянки (археологічного юніту 3), які належать до раннього мезоліту, мають виключну збереженість завдяки швидкому накопиченню седименту та нечастим заселенням гроту. Їхня планіграфія, кількість та склад артефактів дозволяють скласти уяву про особливості господарського використання ландшафтів та скельних жител Кримського високогір'я в цей час.

Культурні шари археологічного юніту 3 датуються часом від 11500 до 7600 років саІ ВР (табл. 1), тобто припадають на ранній пребореал. В цей час клімат був холодніший та вологіший за сучасний, плоскогір'я яйли навколо Шпан-Коби було вкрито мезофітними степами, на схилах гір росли сосна, береза та ялівець (Gerasimenko et al. in press.). За археозоологічними даними тваринний світ яйли включав таких представників степових ландшафтів як сугак та кінь, і, водночас, типово лісових тварин - благородного оленя, рись та бурого ведмедя (Benecke 1999; 2000) (табл. 2).

Всі культурні шари юніту 3 надзвичайно подібні між собою. Вони належать до типу «ефемерних»: представлені невеликими вогнищами, окремими кістками впольованих тварин, та поодинокими крем'яними артефактами. Шари залишені носіями свідерської культури, судячи із вкрай нечисленних крем'яних виробів, серед яких: свідерські наконечники, сегмент, платівки з притупленим краєм, серединні різці, платівки зняті 3 двоплощинних нуклеусів тощо.

Подібною між собою була й планіграфія всіх шарів юніту 3. Вона відповідає класичній етнографічній «Drop-Toss model» («моделі падіннякидання») Л. Бінфорда, яка описує організацію житлового простору навколо вогнища групою людей від одного до п'яти чоловік (Binford 1978; 1983). Центральним об'єктом в кожному з куль- турних шарів було одне вогнище, діаметром біля одного метра, із тонкою вуглистою лінзою та невеликим прокалом під нею. Навколо вогнищ із західної, південної та південно-східної сторін простежувались три концентричні зони: 1) без знахідок або крем'яними виробами; 2) з дрібними кістками та крем'яними артефактами (зона падіння); 3) із крупнішими кістками (зона кидання). «Асиметричне» розташування знахідок по відношенню до вогнищ свідчить про відсутність штучних житлових конструкцій в гроті. Виключенням $\epsilon$ лише помешкання культурного шару 3-5/6, в якому розкопана невелика стінка з каменів, і для якого за «симетричним» розташуванням знахідок навколо вогнищ можна припускати якусь штучну споруду з рослинних матеріалів, наприклад вітровий заслін чи курінь. Вітровий заслін міг існувати також в помешканні шару 3-2, судячи із відсутності зони кидання в південно-західній частині.

Наявність лише одного вогнища в кожному із культурних шарів, характер розташування артефактів відносно вогнища та їхня кількість, склад мисливської здобичі тощо, свідчать про те, що грот Шпан-Коба в ранньому мезоліті використовувався в якості помешкання невеликою групою людей (до 4-5 чоловік). Заселення, вочевидь, були короткотерміновими, судячи з невеликих та малопотужних вогнищ, вкрай малої кількості кісток тварин та поодиноких крем'яних артефактів, які до того ж знайдені не у всіх шарах. Крім того, більше половини зі знайдених крем'яних виробів мають вторинну обробку, на решті ж - платівках та відщепах, $\epsilon$ сліди використання у вигляді макроретуші. Такий склад крем'яного інвентарю вказує на мисливський «експедиційний» характер поселень в гроті Шпан-Коба. Очевидно, метою його заселень у ранньому мезоліті були відпочинок, оббілування та розробка впольованої здобичі, ремонт мисливського спорядження тощо. Сезонність ранньомезолітичних поселень в гроті за археозоологічними даними припадає на теплу пору року - весну та літо (Benecke 1999, s 83, abb. 10). Ціллю ж мисливських експедицій свідерців на яйлу було полювання, насамперед, на мігруючого сюди із степів Рівнинного Криму сугака, та благородного оленя, чисельність якого також зростала на Першому пасмі Кримських гір в теплу пору року. Кістки бурого ведмедя у багатьох шарах дають підстави припускати, що він також був привабливою здобиччю свідерців Шпан-Коби.

подякИ. Дякую О.О. Кротову за дружні поради та Н.Р. Михайлову за редагування, переклад англійською мовою та допомогу у написанні статті. 


\section{ЛІТЕРАТУРА}

Бадер, О.Н. 1957. Некоторые памятники палеолита и мезолита в восточной части Горного Крыма. В: Шульц, П.Н. (ред.). История и археология Древнего Крыма. К.: Изд-во АН УССР. с. 7-25.

Бадер, Н.О. 1976. Некоторые итоги работ под навесом Буран-Кая в связи с исследованиями раннего мезолита Крыма. В: Кольцов Л.В., Зимина М.П., Гадзяцкая О.С. (ред.). Восточная Европа в эпоху камня и бронзы. Москва: Наука, с. 27-37.

Бонч-Осмоловский, Г.А. 1934. Итоги изучения крымского палеолита. Труды II междунар. конф. Ассочиачии по изучению четвертичного периода Европы. V. Москва-Ленинград-Новосибирск: Гос. Научн.-техн. горно-геологонефтяное изд-во, с. 114-183.

Васильєв, С.О. 1995. Критерії виділення наземних жител пізнього палеоліту. Археологія, 3, с. 131-136.

Векилова, Е.А. 1957. Мезолитическая стоянка Сюрень II (раскопки 1954-1955 гг.). КСИА АН УССР, 7, с. 7, 8.

Векилова, Е.А. 1961. К вопросу о свидерской культуре в Крыму (стоянка Сюрень ІІ). КСИА АН СССР, 82, с. 43-149.

Векилова, Е.А. 1966. К вопросу о связях населения Крыма в эпоху мезолита МИА, с. 144-154.

Векилова, Е.А. 1971. Каменный век Крыма: некоторые итоги и проблемы. МИА, 173, с. 117-161.

Зайцева, Г.И., Тимофеев, В.И., Загорска, И., Ковалюх, Н.Н. 1997. Радиоуглеродные даты памятников мезолита Восточной Европы. Радиоуглерод и археология: Ежегодник радиоуглеродной лаборатории, 2, Санкт-Петербург: Теза, с. 117-127.

Залізняк, Л.Л., Яневич, О.О. 1987. Свідерські мисливці гірського Криму. Археологія, 60, с. 6-16.

Коен, В.Ю. 1996. Сюреньская финальнопалеолитическая культура Крыма. Археологический альманах, 5, с. $199-209$. Колосов, Ю.Г. 1957. Новые неолитические стоянки Крыма (по данным археологических разведок 1955 г.). КСИА AН УCCP, 7, с. 13-16.

Кротова, О.О. 2013. Пізньопалеолітичні мисливці азово-чорноморських степів. К.: Видавець Олег Філюк.

Подгородецкий, П.Д. 1988. Крым. Природа. Симферополь: Таврия, 1988.

Ступак, Д.В. 1999. Технологія розколювання кременю свідерської культури Українського Полісся за аналізом нуклеусів. Vita antiqua, 2, с. 18-25. https://doi.org/10.37098/VA-2019-11-116-137

Яневич, А.А. 1990. Хозяйство мезолитического и неолитического населения Горного Крыма. В: Неприна, В.И. (ред.). Каменный век на территории Украины, К.: Наукова думка, с. 102-111.

Яневич, О.О. 1993. Шпанська мезолітична культура. Археологія, 1, с. 3-15.

Яневич, О.О. 2010. Свідер Криму в контексті фінального палеоліту та раннього мезоліту півдня Східної $Є$ вропи, Матэрыалы па археалогіі Беларусі, 18, Минск, с. 56-73.

Яневич, О.О. 2019. Радіовуглецева хронологія фінального палеоліту, мезоліту та неоліту Криму в археологічному та палеоекологічному контекстах, Vita antiqua, c. 116-137. doi:10.37098/VA-2019-11-116-137

Benecke, N. 1999. Die Tierreste aus dem mesolithischen Abri Span-Koba im Krimgebirge. In: Kokabi, M., May, E. (eds.). Beitrage zur Archaozoologie und Prahistorischen Antropologie, II, s. 71-90.

Benecke, N. 2000. Mesolithic hunters of the Crimean Montains: The fauna from rock shelter of Span'-Koba. In: Mashkour, M., Choyke A.M., Buitenhuis, H., Poplin, F. (eds.). Archaeozoology of the Near East, IV A. Proceedings of the fourth international symposium on the archaeozoology of southwestern Asia and adjacent areas. ARS - Publicate 32, Groningen, The Netherlands, p. 107-120.

Binford, L. 1978. Dimensional Analysis of Behaviour and Site Structure: Learning from an Eskimo Hunting Stand. American Antiquity. 43 (3), p. 330-361.

Binford, L. 1983. In pursuit of the past. Decoding the archaeological records. London, New York: Thames \& Hudson.

Gerasimenko, N.P., Bezusko, L.G., Avdieienko, Y.L., Yanevich A.A. In press. Late Glacial and Holocene vegetational and climate changes and their impact on material cultures in the Crimean Mountains (founded on pollen data from cave deposits). Quaternary International.

Henry, D. 2012. The palimpsest problem, hearth pattern analysis, and Middle Paleolithic site structure. Quaternary International. 247, p. 246-266.

Janevic, Alexander. 1999. Das Swiderien der Krim, Tanged points cultures in Europe, Lublin, s. 36-46.

Lanoe, F., Pean, S., Yanevich, A., 2015, Saiga antelope hunting in Crimea at the Pleistocene-Holocene transition: the site of Buran-Kaya III Layer 4, Jornal of Archaeological Science, 54, p. 270-278. 


\section{REFERENCES:}

Bader, O.N. 1957. Nekotoryye pamyatniki paleolita i mezolita v vostochnoy chasti Gornogo Kryma. In: Shults. P.N. (red.) Istoriya i arkheologiya drevnego Kryma, K.: Izd-vo AN USSR, s. 7-25. (in Russian)

Bader, N.O. 1976. Nekotoryye itogi rabot pod navesom Buran-Kaya v svyazi s issledovaniyami rannego mezolita Kryma. In: Koltsov L.V., Zimina M.P., Gadzyatskaya O.S. (red.). Vostochnaya Evropa v epokhu kamnya i bronzy, Moskva: Nauka. s. 27-37. (in Russian)

Bonch-Osmolovskiy, G.A. 1934. Itogi izucheniya krymskogo paleolita. Trudy Il mezhdunar. konf. Assotsiatsii po izucheniyu chetvertichnogo perioda Evropy, V. Moskva-Leningrad-Novosibirsk: Gos. Nauchn.-tekhn. gorno-geologo-neftyanoye izd-vo, s. 114-183. (in Russian)

Vasyliev, S.O. 1995. Kryterii vydilennia nazemnykh zhytel piznoho paleolitu. Arkheolohiia, 3, s. 131-136. (in Ukrainian)

Vekilova, E.A. 1957. Mezoliticheskaya stoyanka Syuren II (raskopki 1954-1955 gg.). KSIA AN USSR, 7, s. 7, 8. (in Russian)

Vekilova, E.A. 1961. K voprosu o sviderskoy kulture v Krymu (stoyanka Syuren II). KSIA AN SSSR, 82, s. 43-149. (in Russian)

Vekilova, E.A. 1966. K voprosu o svyazyakh naseleniya Kryma v epokhu mezolita. MIA, s. 144-154. (in Russian)

Vekilova, E.A. 1971. Kamennyy vek Kryma: nekotoryye itogi i problemy. MIA, 173. s. 117-161. (in Russian)

Zaytseva, G.I., Timofeyev, V.I., Zagorsk, I., Kovalyukh, N.N., 1997. Radiouglerodnyye daty mezoliticheskikh pamyatnikov Vostochnoy Yevropy. Radiouglerod i arkheologiya 2, 117-127. (in Russian).

Zaliznyak, L.L., Yanevich. O.O. 1987. Sviderski mislivtsi girskogo Krimu. Arkheologiya, 60, s. 6-16. (in Ukrainian)

Koyen, V.Yu. 1996. Syurenskaya finalnopaleoliticheskaya kultura Kryma. Arkheologicheskiy almanakh, 5, s. $199-209$. (in Russian)

Kolosov, Yu.G. 1957. Novyye neoliticheskiye stoyanki Kryma (po dannym arkheologicheskikh razvedok 1955 g.). KSIA AN USSR, 7, s. 13-16. (in Russian)

Krotova. O.O. 2013. Piznopaleolitichni mislivtsi azovo-chornomorskikh stepiv, K.: Vidavets Oleg Filyuk. (in Ukrainian)

Podgorodetskiy, P.D. 1988. Krym. Priroda. Simferopol: Tavriya. 1988. (in Russian)

Stupak, D.V. 1999. Tekhnologiya rozkolyuvannya kremenyu sviderskoi kultury Ukrainskogo Polissya za analizom nukleusiv. Vita antiqua, 2, s. 18-25. (in Ukrainian). https://doi.org/10.37098/VA-2019-11-116-137

Yanevich, A.A. 1990. Khozyaystvo mezoliticheskogo i neoliticheskogo naseleniya Gornogo Kryma. In: Neprina, V.I. (red.). Kamennyy vek na territorii Ukrainy, K.: Naukova dumka, s. 102-111. (in Russian)

Yanevich, O.O. 1993. Shpans'ka mezolitychna kul'tura. Arkheolohiya, 1, s. 3-15 (in Ukrainian).

Yanevich, O.O. 2010. Svider Krimu v kontjeksti finalnoho paleolitu ta ranńoho miezolitu pivdnia Schidnoji Jevropi. Materyały pa archieałohii Biełarusi, 18, Minsk, s. 56-73. (in Ukrainian)

Yanevich, O.O. 2019. Radiovugletseva chronologia final'nogo paleolitu, mezolitu ta neolitu Krymu v arheologichnomu ta paleoekologichnomu konteksti. Vita Antiqua, 11, s. 116-137. (in Ukrainian). doi:10.37098/VA-2019-11-116-137

Benecke, N. 1999. Die Tierreste aus dem mesolithischen Abri Span-Koba im Krimgebirge. In: Kokabi, M., May, E. (eds.). Beitrage zur Archaozoologie und Prahistorischen Antropologie, II, s. 71-90.

Benecke, N. 2000. Mesolithic hunters of the Crimean Montains: The fauna from rock shelter of Span'-Koba. In: Mashkour, M., Choyke A.M., Buitenhuis, H., Poplin, F. (eds.). Archaeozoology of the Near East, IV A. Proceedings of the fourth international symposium on the archaeozoology of southwestern Asia and adjacent areas. ARS - Publicate 32, Groningen, The Netherlands, p. 107-120.

Binford, L. 1978. Dimensional Analysis of Behaviour and Site Structure: Learning from an Eskimo Hunting Stand. American Antiquity, 43 (3), p. 330-361.

Binford, L. 1983. In pursuit of the past. Decoding the archaeological records. London, New York: Thames \& Hudson.

Gerasimenko, N.P., Bezusko, L.G., Avdieienko, Y.L., Yanevich, A.A. In press. Late Glacial and Holocene vegetational and climate changes and their impact on material cultures in the Crimean Mountains (founded on pollen data from cave deposits). Quaternary International.

Henry, D. 2012. The palimpsest problem, hearth pattern analysis, and Middle Paleolithic site structure. Quaternary International, 247, p. 246-266.

Janevic, Alexander. 1999. Das Swiderien der Krim, Tanged points cultures in Europe, Lublin, s. 36-46.

Lanoe, F., Pean, S., Yanevich, A., 2015, Saiga antelope hunting in Crimea at the Pleistocene-Holocene transition: the site of Buran-Kaya III Layer 4, Jornal of Archaeological Science 54, p. 270-278. 
1 PHD, research fellow, Institute for Archaeology of the National Academy of Sciences of Ukraine address: Heroiv Stalinhrada ave., 12, Kyiv, 04210, Ukraine ORCID: $0000-0002-8088-6950$

e-mail: alexandr yanevich@iananu.org.ua

\section{EARLY MESOLITHIC HABITATION IN THE SHPAN-KOBA GROTTO (CRIMEA, UKRAINE)}

Shpan-Koba Grotto is currently the only stratified Mesolithic and Neolithic site on the plateau of the First Range of the Crimean Mountains (Yayla). Lower Early Mesolithic cultural layers of the site (archaeological unit 3) have exceptional preservation due to the rapid accumulation of sediment and infrequent settlement of the grotto. Their planigraphy, number and composition of the artifacts can tell about the peculiarities of the economical use of the landscapes and rock shelter of the Crimean highlands at that time.

Cultural layers of archaeological unit 3 date back to time from 11500 to 7600 years cal BP, which belongs to Early Preborial. At this time, the climate was colder and wetter than today, the plateau of the Yayla around Shpan-Koba was covered by mesofit steppes, pine, birch and juniper grew on the slopes of the mountains. According to archaeozoological data, the fauna of the Yayla included such representatives of steppe landscapes as saiga and horse, and simultaneously typical forest animals - red deer, brown bear and lynx.

All cultural layers of the unit 3 are very similar. They belong to the type of «ephemeral»: are represented by small fires, few bones of hunted animals and single flint artifacts. The layers were left by the bearers of the Swiderian culture, due to very few flint artifacts, among them: swidrian points, segment, backed blades, straight dihedral burin, endscrapers. More than half of the found flint artifacts are retouched tools, the rest - blades and flakes, have the traces of use in the form of macro retouch. Such composition of the flint inventory indicates on the hunters ("expeditional") character of the habitations in the Shpan-Koba grotto.

The planigraphy of all layers of the unit 3 was similar too. It corresponds to classic ethnographical «Drop-Toss model» be L. Binford, which describe the organization of the living space around the hearth by a group of people from one to five people (Binford 1978; 1983). The central object in each of the cultural layers was one hearth about one meter in diameter with the thin charcoal lens and little piece of burned clay under it. Three concentric zones were traced around the hearths on the western, southern, and southeastern sides: 1) without artifacts; 2 ) with little bones and flint artifacts (Drop zone); 3) with bigger bones (Toss zone). The «asymmetrical» location of the finds in relation to the hearths indicates the absence of artificial housing in the grotto. The only exception is the habitation of the 3-5/6 cultural layer, in which a small wall of stones was excavated. For it, the «symmetrical» location of the finds around the hearths can be assumed to be an artificial structure made of plant materials, such as a brush windbreak or a hut. The windbreak could also exist in the habitation of layer 3-2, judging by the lack of a Toss zone in the south-western part.

The presence of only one hearth in each of the cultural layers, the location of the artifacts relative to the hearth and their number, the composition of hunting prey, etc., evidence, that Shpan-Koba grotto in the Early Mesolithic was used as dwelling of little group (4-5 people). The occupation, probably, was very short terming, due to small and lowpower fires, very few bones of animals and single flint artifacts, which were found in certain layers. Their purpose was recreation, skinning and butchering of hunting prey, repair of hunting equipment and more.

Seasonality of the Early Mesolithic dwellings in the grotto, due to archaeozoological data, fall on warm time spring and summer (Benecke 1999, s 83, abb. 10). The aim of the swidrian people's hunting expeditions to Yaila was hunting, first, on the saiga and red deer, which migrated from from the steppes of northern Crimea. The number of the red deer also increased in the First Range of the Crimean Mountains during warm seasons. The bones of the brown bear in many layers suggest that it was also an attractive prey.

Keywords: Crimea, Ukraine, Early Mesolithic, habitation, seasonal migrations, Swiderian. 


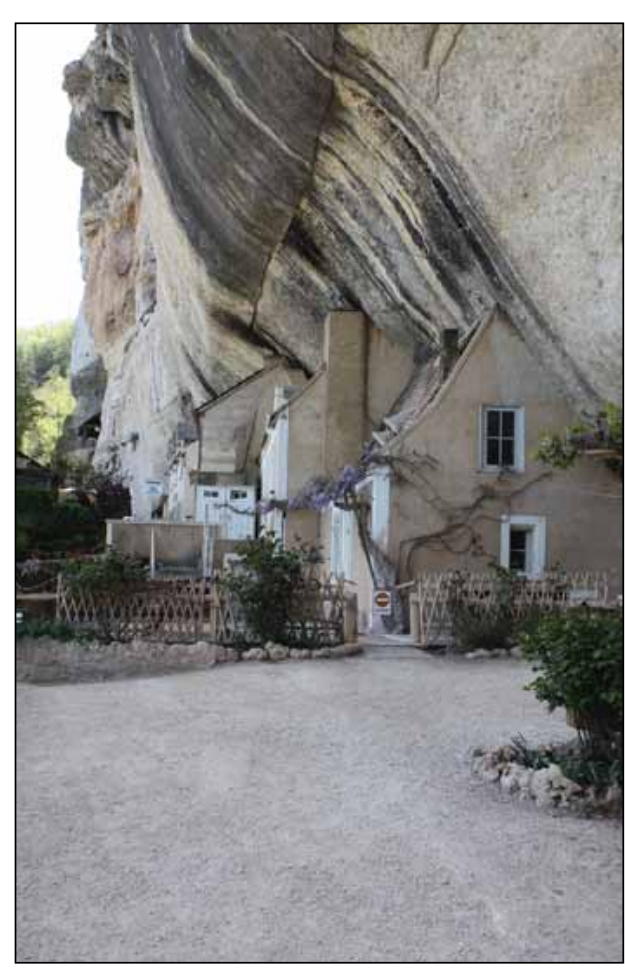

Рис. 1. Сучасні будинки під скельним навісом Ложері-Бас (Лез-Езі-де-Тейяк-Сюрель, Дордонь, Франція). Під цим же скельним навісом знаходиться пізньопалеолітична стоянка Ложері-Бас Фото автора.

Fig. 1. Modern buildings under the rock shelter in Laugerie-Bass (Les Eyzies-de-Tayac-Sireuil, France). Upper Palaeolithic site Laugerie-Bass is under this shelter too. Author's photo.

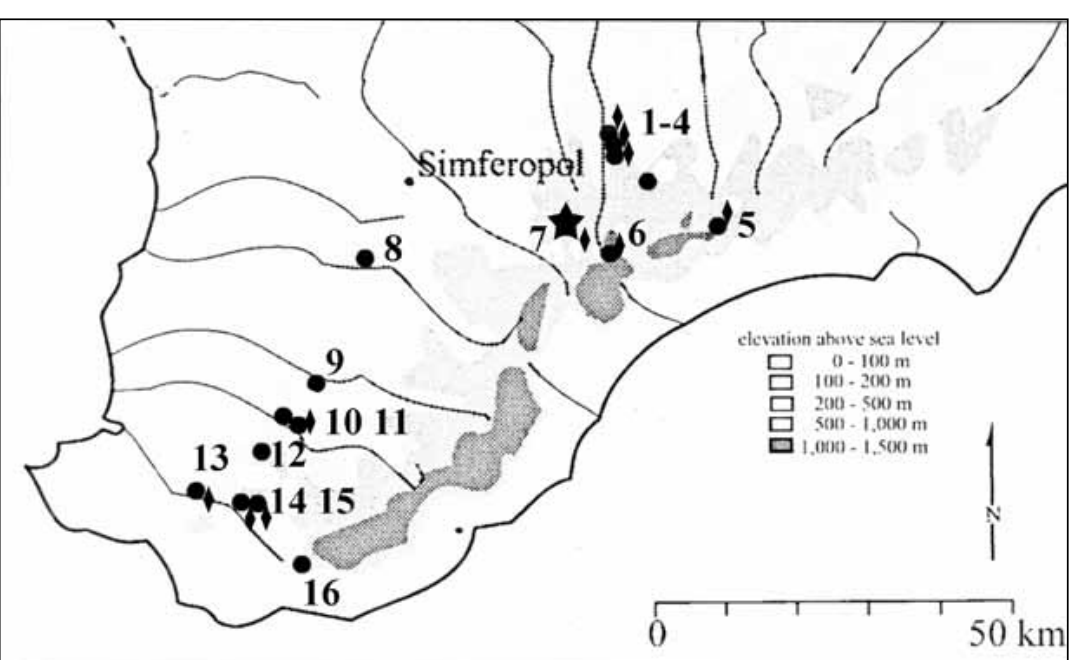

УМОВНІ ПОЗНАЧКИ:

пам'ятки фінального палеоліту та раннього мезоліту грот Шпан-Коба

пам'ятки фінального палеоліту та раннього мезоліту, які містять також шари свідерської культури

Рис. 2. Стоянки фінального палеоліту та раннього мезоліту Гірського Криму: 1 - БуранКая грот; 2 - Буран-Кая навіс; 3 - Буран-Кая 3; 4 - Буран-Кая 4; 5 - Ала-Чук; 6-Су-Ат 3;7-Шпан-Коба; 8-Грот Скелястий; 9-Алимівський навіс; 10-Сюрень; 11 - Сюрень Il; 12 - Заміль-Коба l; 13 - Мурзак-Коба; 14 - Шан-Коба; 15 - ФатьмаКоба; 16 - Грот Водопадний.

Fig. 2. Final Palaeolithic and Early Mesolithic sites of Crimea: 1 - Buran-Kaya grotto; 2-Buran-Kaya shelter; 3. - Buran-Kaya 3; 4-Buran-Kaya 4; 5 - Ala-Chuk; 6 - SuAt 3; 7 - Shpan-Koba; 8 - Skelyasty grotto; 9 - Alymovsky shelter; 10 - Siuren I; 11 - Siuren Il; 12 - Zamil-Koba l; 13 - Murzak-Koba; 14 - Shan-Koba; 15 - FatmaKoba; 16 - Vodopadny grotto.

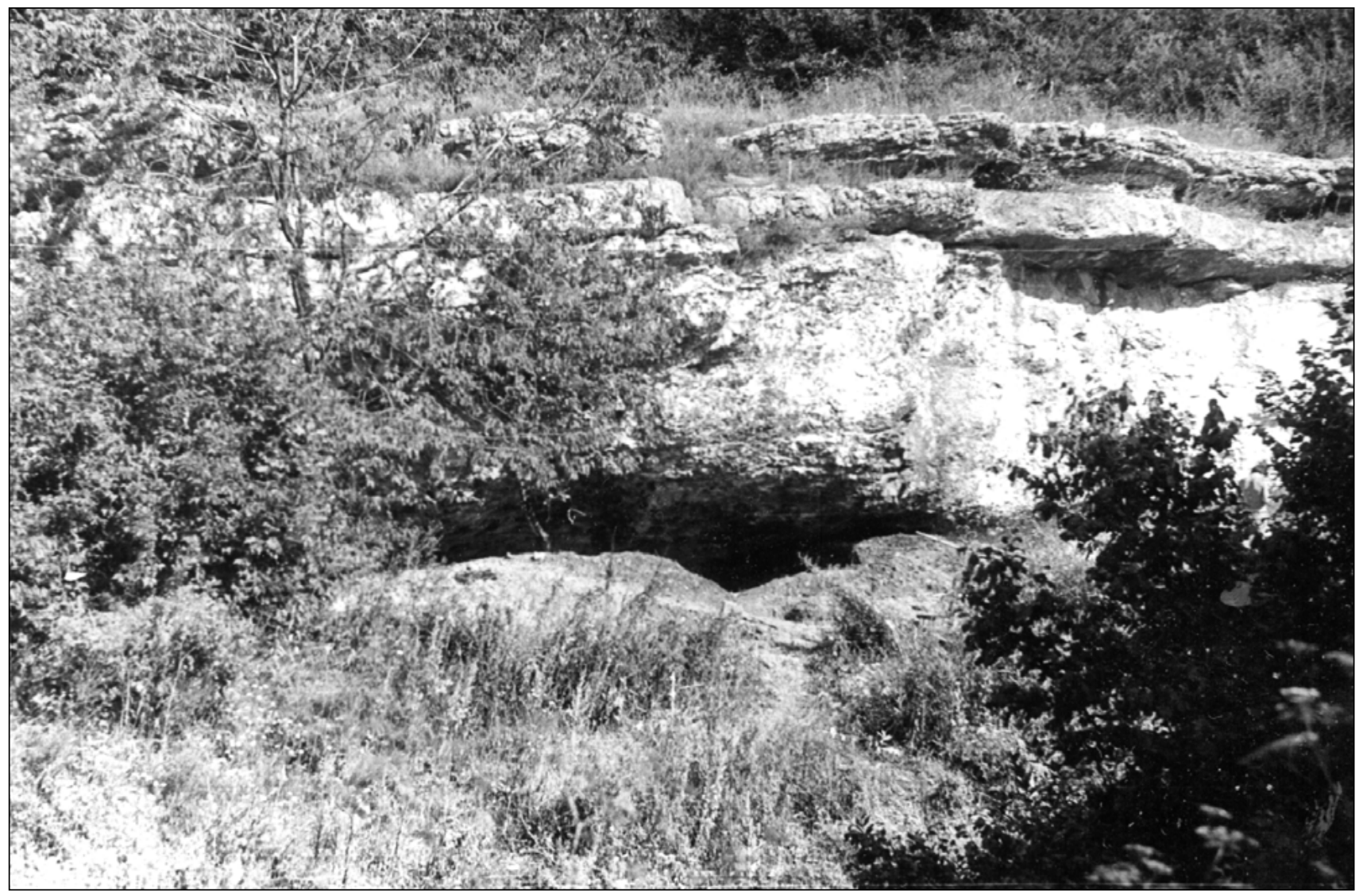

Рис. 3. Шпан-Коба. Вид стоянки зі сходу.

Fig. 3. Shpan-Koba. View of the site from the East. 


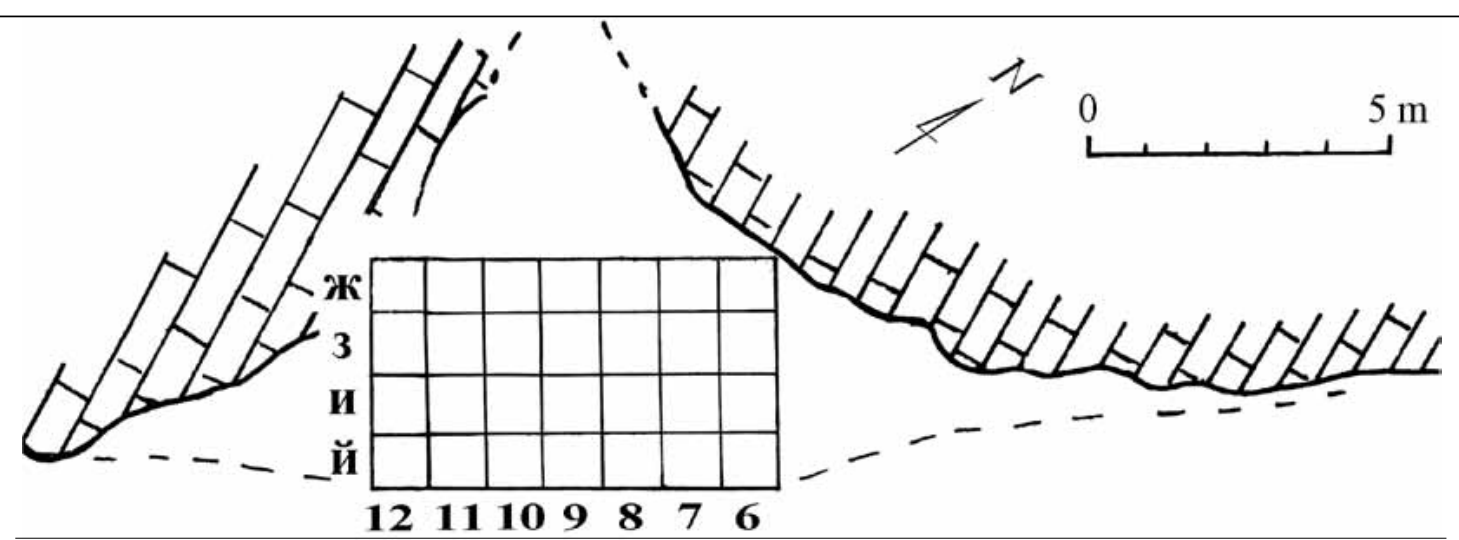

Рис. 4. Шпан-Коба. План стоянки та розкопу.

Fig. 4. Shpan-Koba. The plan of the site and excavation.
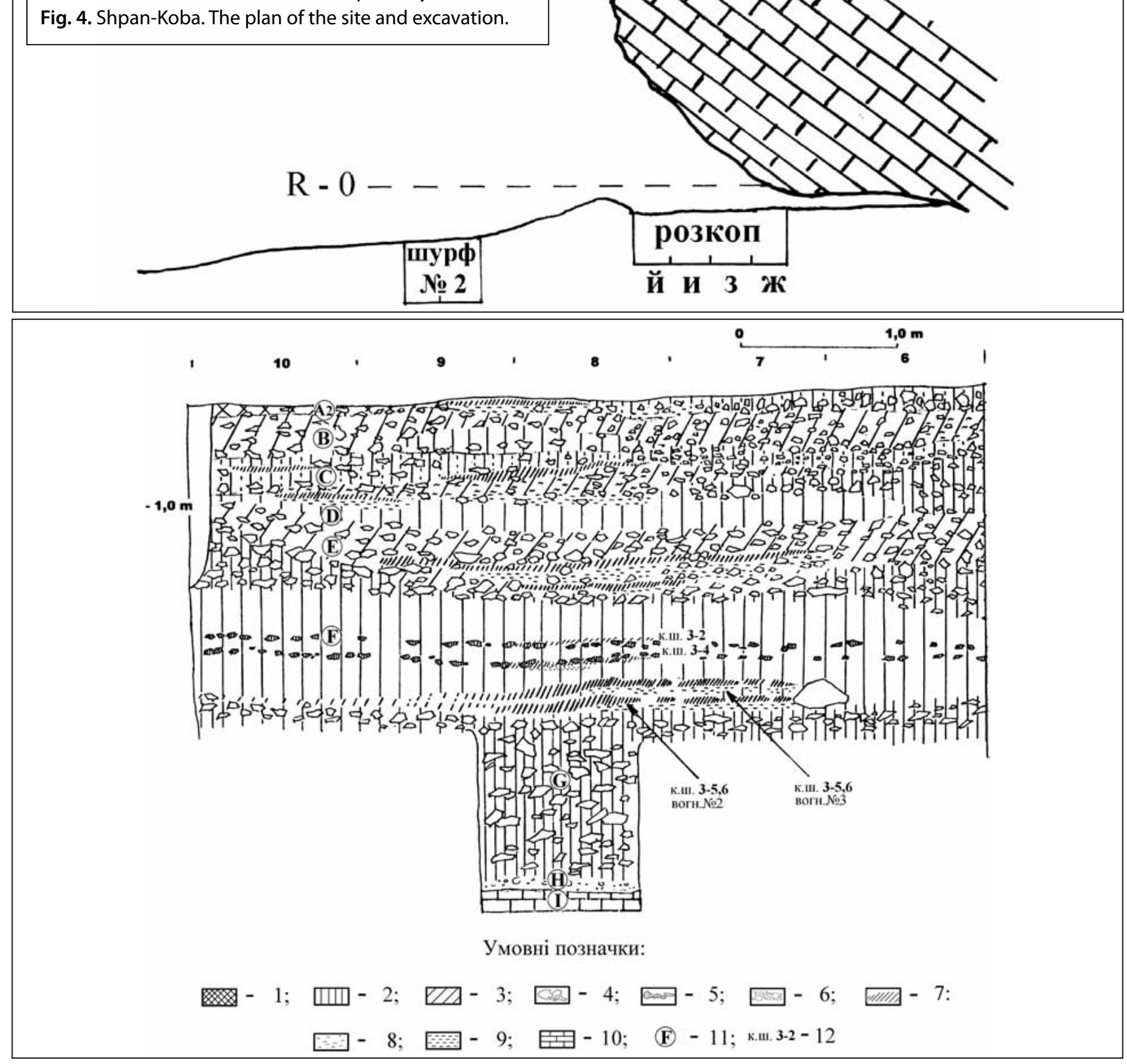

Рис. 5. Шпан-Коба. Профіль відкладів по лінії «и». Умовні позначки: 1 - вуглистий суглинок; 2 - жовтувато-коричневий суглинок; 3 - червоно-кричневий суглинок; 4 - камені; 5 - білоглазка; 6 - кварцева галька; 7 - вуглисті відклади; 8 - зола; 9 - прокал; 10 - скельне дно; 11 - літологічний шар; 12 - культурний шар.

Fig. 5. Shpan-Koba. Cross-section of the stratigraphy on the line " $и$ ". Legend: 1 - fire-burnt clay; 2 - yellowish-brown clayey loam; $3-$ reddish-brown clayey loam; 4 - limestone stones; 5 - white spots of lime in soil; 6 - quartz pebbles; 7 - carbonaceous deposits; 8 - ash; 9 - burnt sediment; 10 - rock bottom; 11 - lithological layer; 12 - cultural layer. 


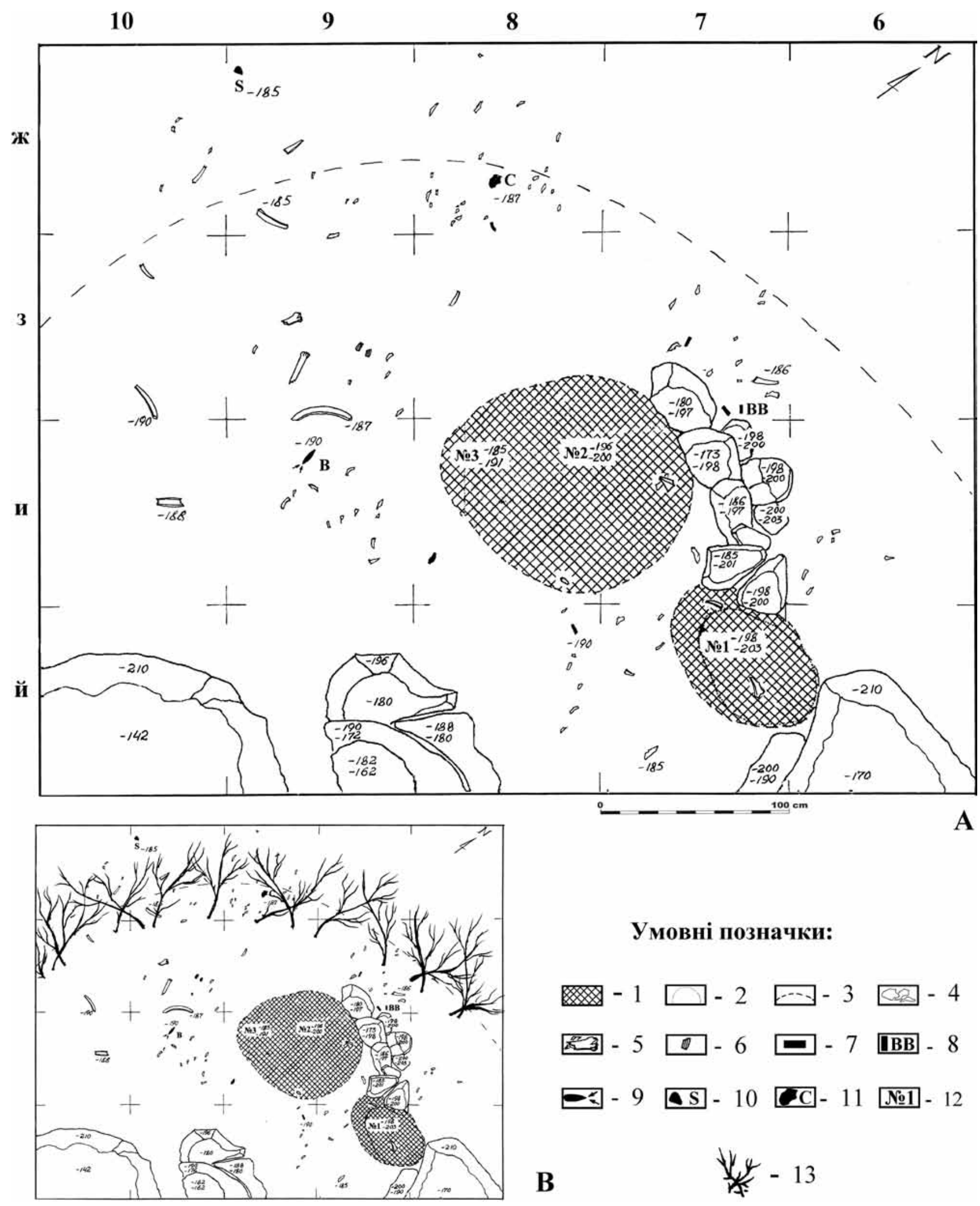

Рис. 6. Шпан-Коба. Культурний шар 3-5/6: А 一 план шару; В — реконструкція помешкання. Умовні позначки: 1 - вогнище; 2 - прокал; 3 - межа поширення вуглистого седименту; 4 - каміння; 5 - кістка; 6 - зуб; 7 - платівка; 8 - платівка з притупленим краєм; 9 - різець; 10 - скребачка; 11 - нуклеус; 12 - номер вогнища; 13 - гілки дерев.

Fig. 6. Shpan-Koba. Cultural layer 3-5/6: A - plan; B - reconstruction of habitation. Legend: 1 - fire; 2 - burnt sediment; 3 - carbonaceous sediment boundary; 4 - stones; 5 - bone; 6 - tooth; 7 - blade; 8 - backed blade; 9 - burin; 10 - scraper; 11 - core; 12 - number of the fireplace; 13 - tree branches. 


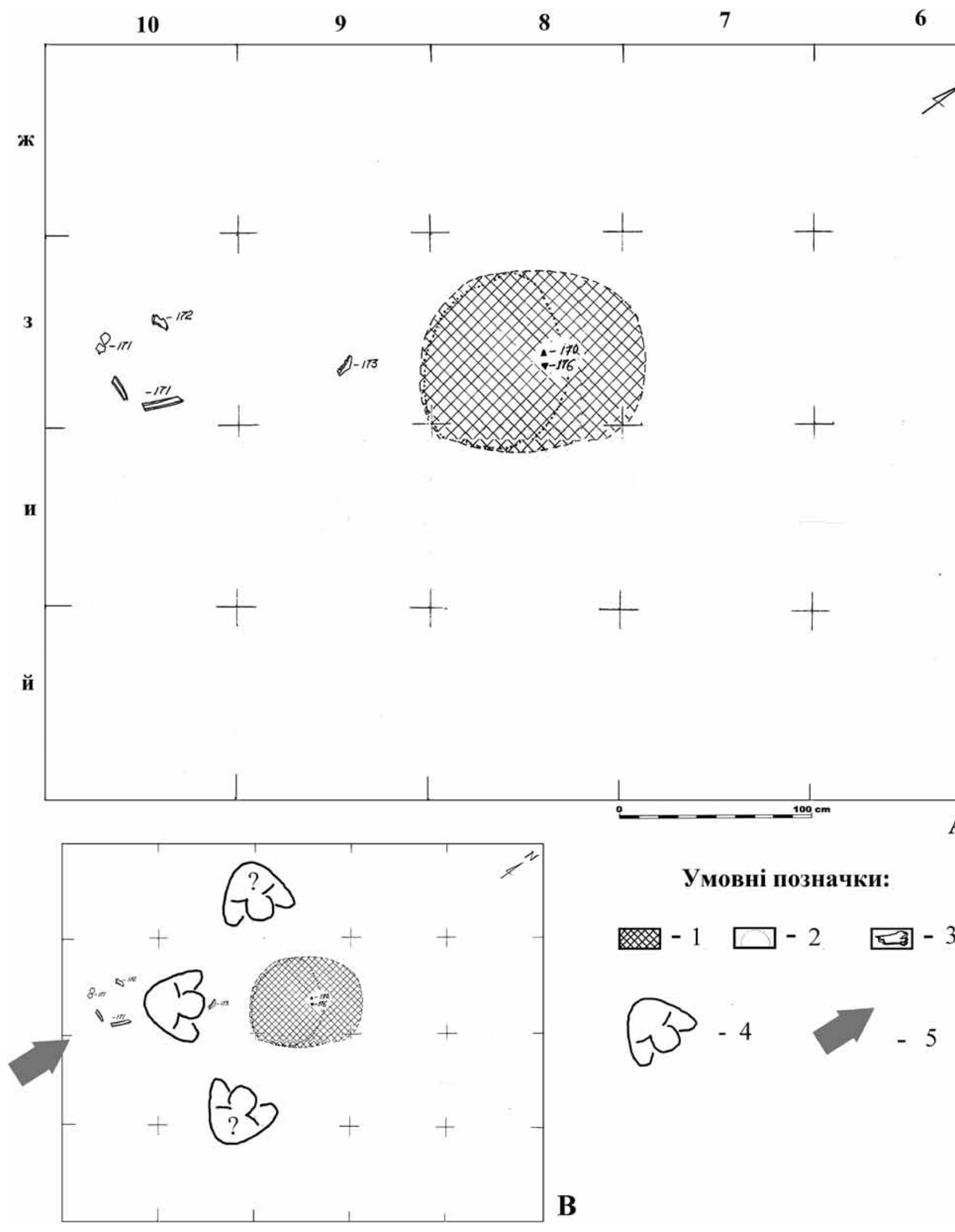

Рис. 7. Шпан-Коба. Культурний шару 3-4: A — план шару; В — реконструкція організації помешкання. Умовні позначки: 1 — вогнище; 2 - прокал; 3 - кістки; 4 - місце, де сиділи люди; 5 - напрямок вітру.

Fig. 7. Shpan-Koba. Cultural layer 3-4: A — plan; B — reconstruction of habitation. Legend: 1 - fire; 2 - burnt sediment; 3-bones; 4-squat place; 5 - wind direction. 

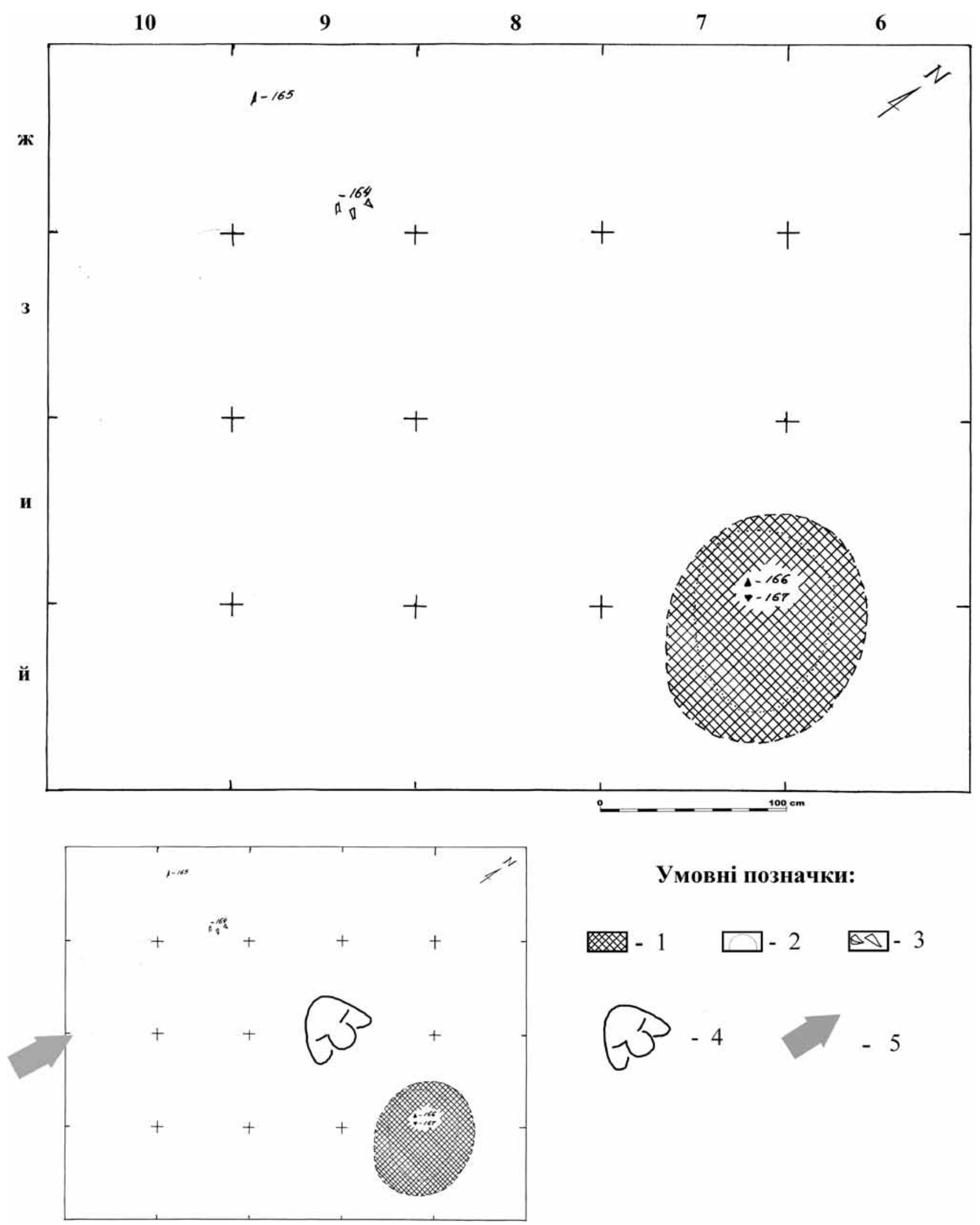

\section{Умовні позначки:}

- $1 \square-2 \square-3$

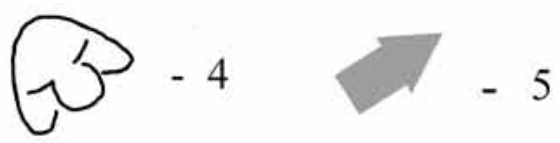

Рис. 8. Шпан-Коба. Культурний шар 3-3: А — план шару; В - реконструкція організації помешкання. Умовні позначки: 1 - вогнище; 2 - прокал; 3 - кістки; 4 - місце, де сиділи люди; 5 - напрямок вітру.

Fig. 8. Shpan-Koba. Cultural layer 3-3: A - plan; B - reconstruction of habitation. Legend: 1 - fire; 2 - burnt sediment; 3 - bones; 4 - squat place; 5 - wind direction. 


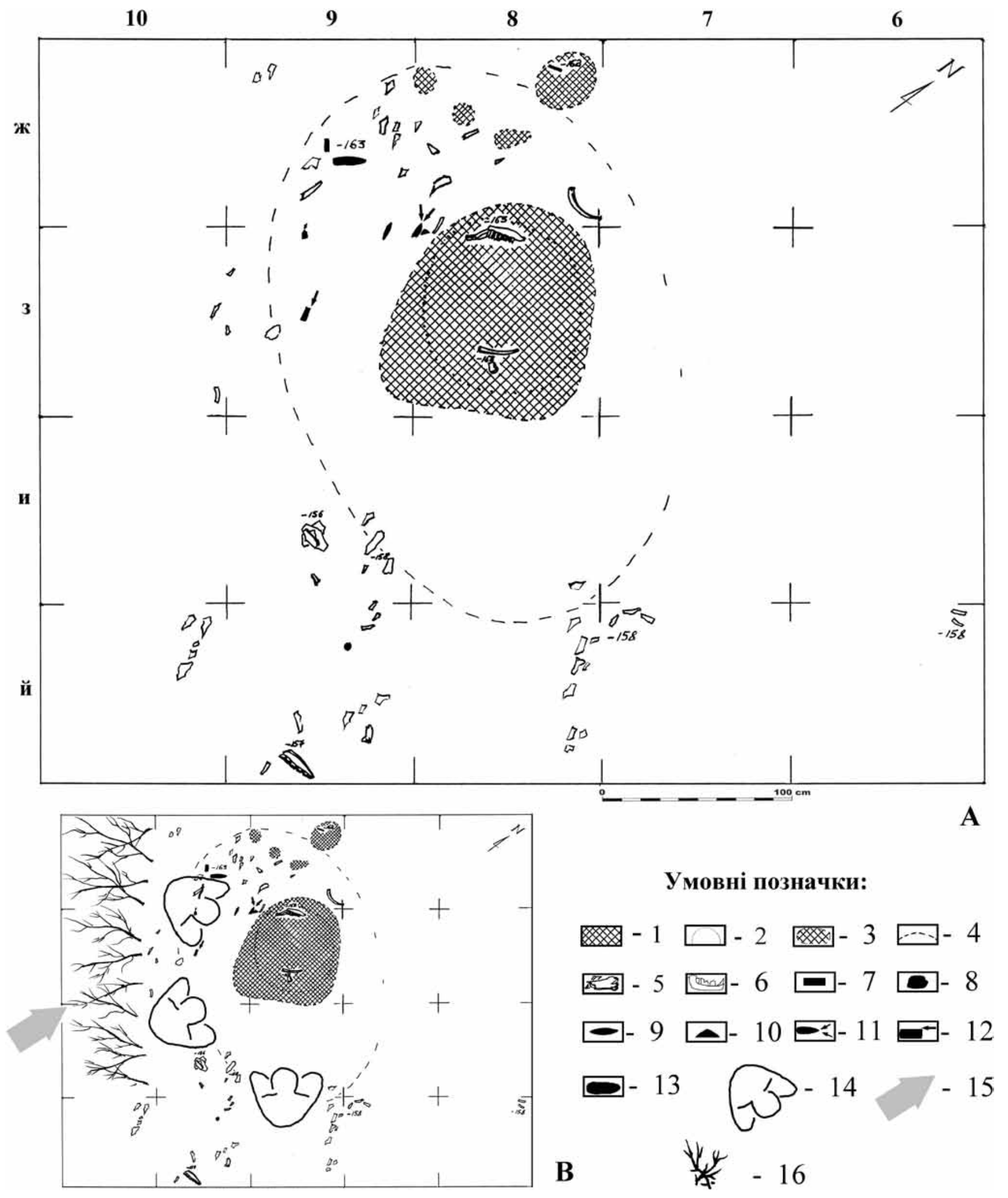

Рис. 9. Шпан-Коба. Культурний шар 3-2: А — план шару; В - реконструкція організації помешкання. Умовні позначки: 1 - вогнище; 2 - прокал; 3 - головня; 4 - межа вуглистого седименту; 5 - кістка; 6 - щелепа; 7 - платівка; 8 - відщеп; 9 - свідерський наконечник; 10 - сегмент; 11 - різець; 12 - різець; 13 - велика платівка з ретушшю; 14 - місце, де сиділи люди; 15 - напрямок вітру; 16- вітровий заслін з гілок.

Fig. 9. Shpan-Koba. Cultural layer 3-2: A - plan; B - reconstruction of habitation. Legend: 1 - fire; 2 - burnt sediment; 3 - brand; 4 - carbonaceous sediment boundary; $5-$ bone; $6-$ jaw; 7 - blade; 8 - flake; 9 - swidrian point; $10-$ segment; $11-$ burin; 12 - burin; 13 - big retouched blade; 14 - squat place; 15 - wind direction; 16 - brush windbreaker. 


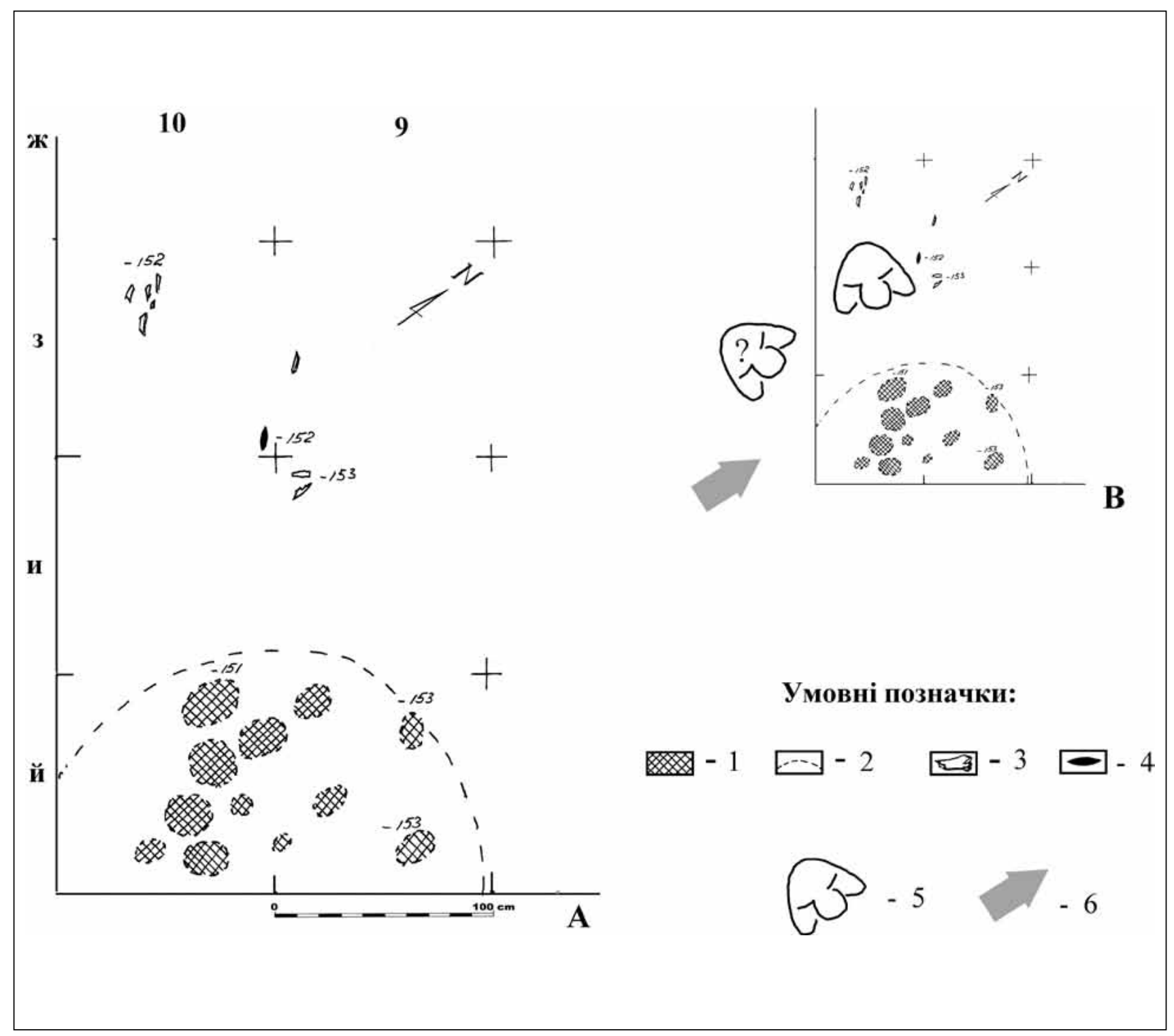

Рис. 10. Шпан-Коба. Культурний шар 3-1: А — план шару; В - реконструкція організації помешкання. Умовні позначки: 1 - вуглисті скупчення; 2 - кістки; 3 - свідерський наконечник; 4 - місце, де сиділи люди; 5 - напрямок вітру.

Fig. 10. Shpan-Koba. Cultural layer 3-1: A — plan; B - reconstruction of habitation. Legend: 1 - coal clusters; 2 - bones; 3 - swidrian point; 4 - squat place; 5 - wind direction. 


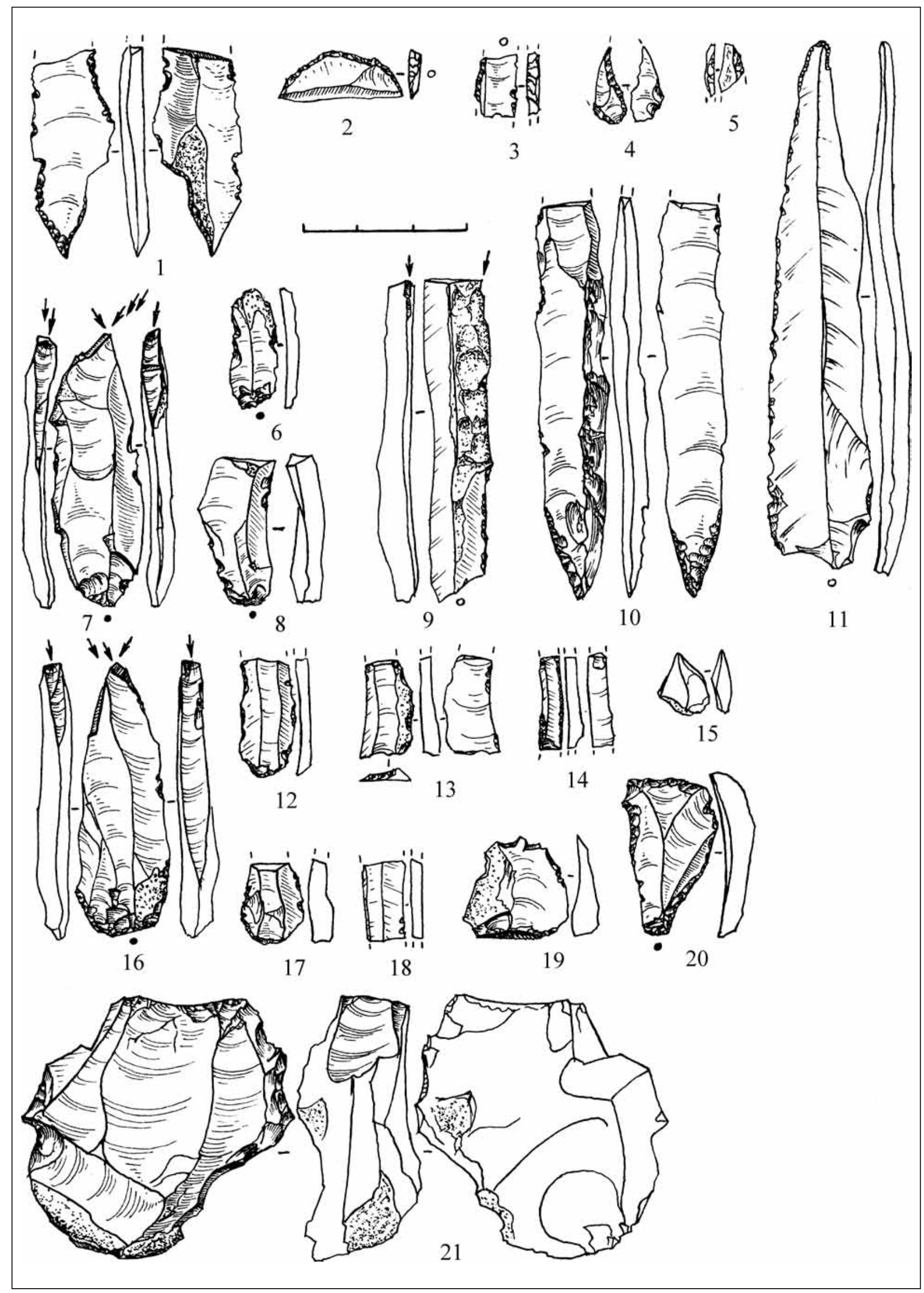

Рис. 11. Шпан-Коба. Крем'яний інвентар культурних шарів 3-1 (1), 3-2 (2-11) та 3-5 (12-22).

Fig. 11. Shpan-Koba. Flint inventory of the cultural layers: 3-1 (1), 3-2 (2-11), 3-5 (12-22). 
